\title{
Dynamics of firm-level upgrading and the role of learning in networks in emerging markets
}

\author{
Deniz E. Yoruk \\ Aston University \\ Aston Business School \\ Aston triangle \\ Birmingham, B4 7ET, UK \\ d.yoruk-woodward@aston.ac.uk
}

\begin{abstract}
This paper investigates which external learning mechanisms in networks contribute to various upgrading types in emerging market firms, and how internalisation of externally acquired knowledge complements external learning. It develops a dynamic model of firm-level upgrading for analysis, where learning in networks is emphasized. Methodologically, it applies a new approach through a comprehensive analysis of a firm's networks embedded not only in production systems (i.e. GVCs/GPNs) but also in knowledge systems. Primary data is collected through in-depth interviews with Polish food-processing and clothing firms. Multinomial logistic regression analysis is applied on a dataset of networks of these firms over 12 years covering the transition period. We find that the key source of process upgrading is learning in knowledge networks as opposed to that of in GVCs. Strikingly, learning-by-interacting in GVCs impedes not functional, but managerial upgrading, a previously unexplored upgrading type, which is also shown to be a prerequisite for functional upgrading. Finally, whilst learning-by-training and research within the firm is a 'potent' condition for external learning to contribute to all of the upgrading types, it is a 'must' for successful functional upgrading. These findings strongly suggest the importance of an integrative approach to learning in research on upgrading and the complementarity between organisational and technology upgrading.
\end{abstract}

Keywords: upgrading; learning; global value chains; networks; emerging markets; multinomial logistic regression

https://doi.org/10.1016/j.techfore.2018.06.042

(C) 2019, Elsevier. Licensed under the Creative Commons Attribution-NonCommercial-NoDerivatives 4.0 International http://creativecommons.org/licenses/by-nc-nd/4.0/ 


\section{Introduction}

In the last three decades, changes in the structure and location of international production brought about networks of relationships organised around the value chain in which emerging market firms find it easier to participate, namely global value chains (GVCs) (Gereffi 1999, Schmitz 2004, Gereffi et al. 2005) and global production networks (GPNs) (Dicken 1992, Ernst et al. 1998, Borrus et al. 2000, Henderson et al. 2002). Different streams of research simultaneously provide complementary insights, using frameworks based on these external 'production' linkages of the firm; such as industrial organization (Zysman et al. 1997; Ernst 1997, 2001; Gereffi 1999; Gereffi et al. 2005), development studies (Humphrey and Schmitz 2002, 2008; Schmitz 2006) and economic geography (Dicken 1992, Henderson et al. 2002, Coe et al. 2004, 2008, Hess and Yeung 2006, Hess 2008).

These scholars have made considerable progress in examining the role of key events in changing the production structure of various industries to GVCs and GPNs (Dicken 1992, Ernst 1997, Gereffi 1999) and their effects on the upgrading of firms, industries and countries (e.g., Ernst 1997, Ernst et al. 1998, Schmitz 2004, Bair and Gereffi 2008). Research by industrial organization and development economists is largely constrained to the governance issues in the GVCs, and provides hypotheses with regard to distribution gains in the production system (Humphrey and Schmitz 2004, Gereffi et al. 2005, Sturgeon 2008). The major barrier to the upgrading opportunities for developing country firms appear to stem from the lock-in effects of GVCs/GPNs with regard to the information / knowledge flows from lead firms in GVCs and GPNs. These studies have typically viewed industrial upgrading as driven by exogenous factors and although they have recognized the importance of learning that takes place in GVCs/GPNs, they failed to provide a detailed assessment of the learning mechanisms that underlie the endogeneity of networks on the firms' capability building and, therefore, upgrading.

In the last decade, there has been a growing interest in addressing these shortcomings. Scholars that use GPN framework, for example, explicitly separate the notions of GPNs and global innovation and knowledge networks (GINs/GKNs), and explore how integrating into GPNs lead local supplier firms to getting involved in GINs/GKNs or developing their own (domestic) innovation and knowledge networks (Ernst 2008, 2009). Parilli et al. (2013) emphasise the importance of integrating different analytical frameworks (GVCs, global production networks and global innovation networks) in understanding upgrading at firm, industry, local, regional, national and global levels. Pipkin and Fuentes (2017) argue the wider role of actors in national economies (such as state agencies, business associations) other than GVCs in initiating the upgrading process in firms in developing, transition and emerging market economies.

Scholars that use GVC framework place more weight on the knowledge transfer and learning within GVCs (Schmitz 2006) and makes references to learning in different contexts (Sturgeon and Gereffi 2009, Schmitz and Strambach 2009). For instance, Sturgeon and Gereffi (2009) talk about 'upgrading as learning' by linking measurement of upgrading to learning using Lall's (2000) technological classification of goods exports, while Schmitz and Strambach (2009) try to gain insights from innovation systems and GVC perspective to understand the 'organisational decomposition of the innovation process', while Pietrobelli and Rabellotti (2011) identify different learning mechanisms taking place within the GVCs under each governance type as defined by Gereffi et al. (2005), i.e. market-based arm's length, modular, relational, captive relations, and hierarchy. More precisely, how actually GVCs/GPNs play a significant role in learning has not been answered.

Methodologically, the empirical evidence in GVCs/GPNs literature is largely case study-based. Recent work tries to systematically analyse these case studies to enhance our understanding of the upgrading process and the role of actors involved in it (Tokatli 2013, Pipkin and Fuentes 2017, 
Choksy 2018). Nevertheless, as Schmitz (2006) argues, case-study work does not allow us to understand the dynamics of firm-level upgrading. Time-scales for learning and upgrading in the developing country context has always been a concern leading to a search for micro-level paths of technical change and upgrading (Bell 2006, Yoruk and Yoruk 2012). On the other hand, there have also been few accounts that were drawn on quantitative analysis (e.g., McDermott and Correidera 2010), while there are recent efforts to develop metrics for technological upgrading (Radosevic and Yoruk 2015, 2016, 2018).

This paper contributes to these concerns by investigating the role of 'networks' in leading to upgrading trajectories at the firm-level by examining the learning processes - a combination of interand intra-organisational learning mechanisms. The specific question addressed in this paper is - how involvement in networks brings about firm-level upgrading over time. The time period investigated covers the transition years of an emerging market country, Poland, before accessing the European Union in 2004. This task is important as the debate on shifting wealth indicates an end to the high output growth that was experienced in the emerging markets since the 2000s as a result of the involvement and learning in GVCs/GPNs and raises questions as to whether the emerging markets will be able to fuel their growth by means of sustainable technological upgrading.

The paper builds a 'dynamic model of firm-level upgrading' where a deeper analysis of learning in a variety of networks form the core of upgrading processes within the firm. In doing so, we hope to make three contributions to the upgrading literature. Firstly, the dynamic model takes into account the influence of networks that evolve within knowledge and market systems, which cannot be isolated from the environment created by the GVCs/GPNs. So, alongside GVC/GPN framework, it also relies on network theories of the firm that view networks as sources of external knowledge and learning. Secondly, the dynamic model bridges the gap between networking and firm-level upgrading by building on the literature on organisational learning. An investigation of internalisation of externally acquired knowledge allows us to identify the learning mechanisms in networks that are conducive to potential upgrading. Firm-level upgrading becomes not a function of external learning mechanisms but a function of external learning mechanisms and the internalisation processes that follow the acquisition of external knowledge. Thirdly, by utilizing a unique primary data of Polish food-processing and clothing firms' networks, this paper offers one of the few quantitative analyses of the relative impact of a variety of learning mechanisms in a broader range of networks than GVCs/GPNs on upgrading in emerging market firms, and provides a representative pattern of upgrading for LMT firms' developmental progress during transition years.

Our findings shed light on the current debate on functional upgrading - the desirable upgrading type for sustainable economic development - in the literature; why some local suppliers in GVCs/GPNs can achieve functional upgrading but some cannot (Schmitz2006), whether it is right to blame the discouragement and obstacles put up by the powerful global buyers (Tokatli 2013), whether we need a new typology of functional upgrading and downgrading (Blazek 2015) and so on. Our findings demonstrate that the GVCs/GPNs play an important role in creating learning opportunities for local suppliers, but for this to turn into functional upgrading within the firm over time, the idiosyncratic internal dynamics of the firm is crucial, more precisely its attention to internalising the externally acquired knowledge effectively through in-house training and research (indicating presence of some degree of absorptive capacity). Moreover, our understanding of the developmental process for functional upgrading is also enhanced with the introduction of a new, unexplored, upgrading type, namely managerial upgrading. Our findings show that despite GVCs/GPNs hinder managerial upgrading, achieving managerial upgrading lays the foundations of functional upgrading for emerging market firms during transition years. 
The structure of the rest of the paper is as follows. Section 2 will develop the conceptual framework, which creates the dynamic model of firm-level upgrading. Section 3 introduces the research design and methodology. Section 4 presents the regression results of upgrading models specified. Section 5 discusses these results in the light of the upgrading literature. Section 6 concludes.

\section{Towards a Conceptual Framework of Firm-level Upgrading}

\subsection{Definition of firm-level upgrading re-visited}

In the literature, the concept of upgrading is originally located within the boundaries of production systems, as a result of the fragmentation of value chains and delocalisation of production activities beyond the boundaries of the firm and across national borders since the late 1990s. It is treated as hierarchical improvements with regard to various dimensions, i.e. shifting from one stage or position to another in GVCs/GPNs as upgrading takes place (Ernst 1998, 2001, Gereffi 1999, Schmitz 2004, Gereffi et al. 2005). It has evolved around the idea of improvements from worse to better, from low to high, from shallow to deep, and so on. As a result, the definition and operationalisation of the concept have, thus far, been based on this hierarchical change from low to high 'value-added' (in relation to value chain); in other words, been narrowed down to moving up from one position to another in the value chain, or in comparison with competitors (Meyer-Stamer 2004).

It is no coincidence that a discontent among scholars regarding the definition, typology and operationalisation of upgrading has evolved over the years (Bair 2005, Ponte and Ewert 2009, Brewer 2011, Tokatli 2013, Coe and Yeung 2015, Pipkin and Fuentes 2017). As well as 'downgrading' happening at the same time as upgrading in GVCs (Blazek 2015), too narrow definition of upgrading leads to confusion between the means (e.g. external sources other than GVCs, strategies pursued by the firms, etc.) and the ends of upgrading (e.g. capturing high value-added activities in GVCs, firm growth, etc.) and proves difficult to demonstrate empirically (Bair 2005, Coe and Yeung 2015).

This paper views firm-level upgrading as a building block or step towards the growth of the firm. So, it proposes firm-level upgrading to be considered as a move from being less competitive to being more competitive, from being less competent for efficient resource acquisition and allocation to being more competent, and from being a low level learning organisation to being high level.

We suggest an operational definition of upgrading as follows: Firm-level upgrading refers to the process of gradually acquiring, or enhancing, the deficient intangible assets that enable firms to do things differently and/or better and to do different things as compared to the previous context of the firms' environment.

In the context of emerging market firm, firm-level upgrading is about the distinction between to learn how to do something that was already created in a different way, but not necessarily to create it, and to learn how to create something (see Kogut and Zander 1992:391 regarding "being taught to do something and being taught to create something"). Hence, firm-level upgrading becomes, particularly in the transition years, more about adoption and utilisation, and less about creation, of new and existing technology and knowledge, and it benefits from the effective diffusion of technology and knowledge. "[W]hile firm's processing of knowledge is itself unobservable, it nevertheless influences other, more readily observable organisational practices (Schein 1985)" (Lane and Lubatkin 1998: 465), as manifests itself in minor improvements to products, to more efficient and flexible processes, and later the introduction of new variations of products (Hobday 2003). Drawing on the literature on learning in developing countries, these minor improvements and changes appear to be the key sources of upgrading in the emerging market firms through a 'reversed 
learning sequence' of first inter-organisational and then intra-organisational learning (when compared to developed countries) (Hobday 1995, Kim 1997).

Organisational learning literature suggests that tapping into new knowledge through networks is a required step for the emerging market firm so as to pursue learning and exploit opportunities for capability development. The earliest examples to learning through networks comprised of the work of Hobday (1995b \& c) and Gereffi 1999b) where they build their model on the OEM-ODM-OBM ${ }^{1}$ learning trajectory of the latecomer firm in GVCs or GPNs, and showed the importance of incremental and minor improvements for catching up with developed country firms not through conventional 'learning by doing' (Arrow 1962) but through 'technological learning' which requires "substantial and deliberate effort and investment on the part of firms" (Hobday 1995b: 33, 2003). $\operatorname{Kim}(1997,1999 \mathrm{~b}, 2001)$ refers to this as the 'intensity of effort' component of Cohen and Levinthal's $(1989,1990)$ 'absorptive capacity', which refers to the ability through which external knowledge is internalised and in-house R\&D activities involve not only new knowledge generation but also assimilation of external S\&T. Such effort leads to not only improvements in in-house operational production capabilities but also development of other capabilities that are deficient in the firm.

Therefore, knowledge transfer and learning through networks become a key, inherent source of upgrading in the emerging market firm, as it paves the way for improving technological and organisational deficiencies in the knowledge base of the firm.

\subsection{A contribution to the typology of firm-level upgrading: Managerial upgrading}

Being primarily concerned with knowledge acquisition and internalisation for technological and organisational improvements in the firm, the typology of upgrading as described by Humphrey and Schmitz (2004) is the most suitable categorisation of the firm-level upgrading for operationalisation purposes of this research. Their typology is not only standard categories that are applicable to any sector but also empirically easy to use, particularly when compared to the upgrading trajectory of OEM-ODM-OBM which is more suitable for buyer-driven GVCs/GPNs (Hobday 1995, Gereffi 1999). However, we adopt them with some changes and adaptations ${ }^{2}$ in association with the abovementioned operational definition of firm-level ugrading.

Table 1 demonstrates the categories of firm-level upgrading considered in this paper, alongside with their definitions. Among them, the product and process upgrading are the most straighforward ones.

As Freeman (1994) notes, there are industries that do not require R\&D for innovativeness, particularly those in which organisational innovations are more important than technical innovations (see also von Tunzelmann and Acha 2005). Instead the introduction of new and different firm functions, competences and strategies is what firms operating in these industries need. This is what lies at the core of functional upgrading. The new technologies may cause changes in "the basic parameters of designing, producing and marketing industrial products and services", but they "require significant organisational change" (Radosevic 1999a: 79). This encourages 'the endogenisation of change itself', transforming firms into dynamic learning organisations rather than users of technology for a once-and-for-all change in production (Kaplinsky and Hoffman 1992, Radosevic 1999a). Hence, the acquisition of new functions comes with capabilities to manage. A firm

\footnotetext{
${ }^{1}$ Original Equipment Manufacturing (OEM), Original Design Manufacturing (ODM) and Original Brand Manufacturing (OBM). The OEM-ODM-OBM learning trajectory explains the process of initially manufacturing for low-end markets (as OEMs), then moving up to more demanding and sophisticated markets (as ODMs), and then to high value-added markets (as OBMs).

${ }^{2}$ We leave out inter-sectoral upgrading, which is not relevant to the scope of this research, for reasons of the geography and time period concerned, as well as due to the fact that too little time had elapsed in transition countries at the time of the research for the realisation of chain upgrading.
} 
that achieves functional upgrading normally tends to become a 'network organiser' if this is combined with successful management.

Table 1. Types of firm-level upgrading and their definitions

\begin{tabular}{ll}
\hline \multicolumn{1}{c}{$\begin{array}{c}\text { Type of firm-level } \\
\text { upgrading }\end{array}$} & \multicolumn{1}{c}{ Definition (as applied in this research) } \\
\hline Process upgrading & - increasing the efficiency of existing technological processes within the firm \\
& - introducing new improved production processes for existing products through minor \\
& changes in equipment and capabilities \\
& - re-organisation of production system \\
& - introducing completely new and superior technology for making new products \\
\hline Product upgrading & - 'creative imitation' (Kim 1997) of an existing product and partly about the ability of the \\
& firm to introduce a new product to its market with minor or major changes in the \\
& formulation and/or packaging of the product and/or with the use of new technology \\
& (produced by the firm or imported abroad) \\
& - the expansion of the business via product diversification and/or differentiation (adding \\
& new product categories) and via consumer differentiation (targeting of new consumer \\
& categories) \\
& - the commercial introduction of a new or technically changed product that includes \\
& aesthetic or minor design changes \\
\hline Functional upgrading & - introduction of new and different firm functions (anything other than production \\
& capability), such as design, purchasing, sales, marketing and distribution, that support \\
& development of new and different firm competences and strategies \\
\hline improving the efficiency and effectiveness of production and non-production activities \\
- by acquiring new forms of organisational and managerial methods, such as teamwork, \\
training, quality management, changes in perception of business relationships with \\
suppliers, customers, the implementation of advanced management techniques, the \\
introduction of changes in organisational structures, the implementation of new or \\
substantially changed corporate strategic orientations, and the implementation of quality \\
standards such as ISO 9000 \\
- by re-organizing the existing managerial activities to facilitate internal and external \\
learning (Yoruk 2003,2004)
\end{tabular}

Source: The first three definitions are derived from Kaplinsky and Readman (2000) and Humphrey and Schmitz (2004); the last definition belongs to the author

This brings us to a category of upgrading that is usually overlooked or even forgotten: managerial upgrading, which stems from resource-based view (Penrose 1959, Wernerfelt 1984, Teece et al. 1997). It is particularly important in the context of emerging market firm for skill and resource accumulation, learning in developing new capabilities within the firm and knowledge management for encouraging innovation/upgrading process within the firm. Coombs and Metcalfe (2000) argue that capability development - a backdrop for firm-level upgrading - is related to the division of labour in the generation and exploitation of knowledge (production perspective) as well as the coordination of this division of labour (managerial perspective). Managerial action might also shape networks in an industry as firms strategically manoeuvre to secure key positions in these networks (Hakansson 1987, Teece 1996, Madhavan et al. 1998).

The initial disadvantages of the emerging market firms, e.g. in technological areas can be compensated through managerial upgrading. However, the managerial aspect of firm-level upgrading is less easily transmitted due to its tacit and contextual character (cf. Edquist et al. 2001). Nonetheless, because of the lack of adequate resources, experience and expertise in emerging market firms, networking may change, modify or improve managerial capabilities (Humphrey and Schmitz 2008), with implications for the development and achievement of other upgrading types.

\subsection{Inter-organisational networks and firm-level upgrading}


Networks are a mode of cooperation that allow partners to tap into each other's capabilities or information (Hakansson 1989, Powell 1990, Kogut et al. 1993). Hence, they become not only a major source of technology (not just of machine-centred technological change), knowledge (for production, distribution, marketing, innovation, etc.) and skill transfer among partners (Hamel 1991) but also a potential facilitator of learning (Powell et al. 1996, Uzzi 1997). For emerging market firms, networks represent a tool for (successful) upgrading.

Recent efforts in theorising GVCs/GPNs have depicted them as networks in the sense of transaction cost economics - i.e., an intermediate form of governance between markets and hierarchies located within the boundaries of value chains (Schmitz 2004, 2006; Gereffi et al. 2005). However, bringing all network types under the umbrella of value chain-based governance structures is analytically misleading. Not only there are networking activities where governance is not as dominant as in GPNs/GVCs, but also GVCs and GPNs do not cover the entire external linkages of the firm.

Networks come to life in connection with systems; the GPNs and GVCs that the upgrading literature focuses on stem from production systems; they are about coordination of links and knowledge transfer in globally-dispersed production networks.

Figure 1. A Dynamic Model of Firm-level Upgrading

\begin{tabular}{|l|l|}
\hline \multicolumn{2}{|c|}{ NETWORKS } \\
\hline $\begin{array}{l}\text { Systems: } \\
\text { Production } \\
\text { Knowledge } \\
\text { Market }\end{array}$ & $\begin{array}{l}\text { Geographical } \\
\text { domain: } \\
\text { local } \\
\text { national } \\
\text { international }\end{array}$ \\
\hline
\end{tabular}

Source: Author

This paper employs a broader approach that encompasses networks of knowledge-related flows in sectors between firms and other organisations (see Figure 1). These networks stem from knowledge systems where the firm acquires knowledge from organisations outside the production systems. ${ }^{3}$ Firm-level upgrading then relies on the complementarity between production and knowledge systems within the local, national or international domain, yielding positive effects on the cumulativeness of not only individual absorptive capacity but also organisational upgrading. Knowledge systems have been important to understand the technological dynamics of industries in developed countries, while there is only limited empirical research about how knowledge networks emerge and evolve in the specific context of large firms in developing, emerging and transition economies (Bell and Albu 1999).

The networks originated from production and knowledge systems are considered as embedded networks (Uzzi 1997) as they enable firms to access various knowledge sources, to improve their knowledge stock and existing capabilities, and to develop new competencies through knowledge transfer (Bell and Pavitt 1993, Kim 1998a, Yoruk 2011). However, a firm's networks ideally cover

\footnotetext{
${ }^{3}$ Organizations used in this paper include other firms, universities, research institutes, training centers, consulting firms, business associations and the like (Edquist and Johnson 1997).
} 
both embedded and arm's length ties (i.e. market-mediated ties, Kim 1999a, b) in inter-relations among individuals and firms, and between firms and other organisations (Uzzi 1997). This knowledge transfer is often aimed at changing quality rather than quantity and happens in the areas of market, business, production, technology, innovation.

\subsection{Learning in networks}

The question of how networks play a significant role in an emerging market firm's upgrading is hidden in 'learning in networks', à la Hakansson et al. (1999: 443), who explain it in the simplest form as "learning directly from others", which "means the transfer of knowledge embedded in products or processes or the transfer of knowledge in a more pure form". However, the learning capabilities of emerging market firms partly depend on a broader technological infrastructure that involves external agents (Freeman and Hagedoorn 1994), including 'foreign technology acquisition' (Dahlman and Fonseca 1987, Bell and Pavitt, 1993, Kim 1980, 1997), and partly on a 'reverse learning trajectory' that takes place inside the firm (Kim 1980, 1997, Hobday 1995) with varying absorptive capacity levels (Cohen and Levinthal 1990). These two capabilities have so far been examined separately, leading to a lack of comprehensive understanding of the processes underlying firm-level upgrading. This paper is set to study inter- and intra-organizational learning simultaneously (cf. Easterby-Smith et al. 2008) to observe its implications on the firm-level upgrading.

We define 'learning in networks' as developing the ability to identify and acquire new, potentially useful and valuable external ideas and knowledge while in a relationship and to assimilate this externally acquired knowledge within the firm. So, it is a two-stage learning process, based on the interaction between the two separate learning processes that happen in 'reverse order' when compared to the learning processes adopted by developed country firms (Hobday 1995, Kim 1997).

First stage is manifested in "the ability to exploit knowledge generated by others" as a result of "the firm's access to this knowledge" (Almeida et al. 2003: 303; Inkpen 1998) through networks (i.e. acquisition of new ideas, resources, knowledge or technology). Second stage is about the absorption (Cohen and Levinthal 1990) or internalisation (Hamel 1991) of what is accessed through external relations within the firm, as an integrative and/or complementary part of inter-organisational learning (e.g., Ernst et al. 1998, Kim 1997, Ernst and Kim 2002).

It must be noted that having access to an external source does not necessarily mean the firm is capable of recognizing the vital knowledge (i.e. learning might not occur although there is access to a knowledge source). Similarly, recognizing the importance of external knowledge while having access to it through networking does not necessarily mean the firm can assimilate it (meaning knowledge internalisation such as internal learning and knowledge sharing mechanisms within the firm may be un/under-developed). Linking the ability to acquire new skills and resources externally to the ability to generate internal expertise is at the core of learning in networks (Powell and Grodal 2005). If the same information is delivered to agents that have different cognitive and absorptive capacities, the results will differ (Penrose 1959). To make effective internal use of externally acquired knowledge firms have to learn internalisation (Cohen and Levinthal 1990, Hamel 1991).

Table 2. Learning Mechanisms in Networks as derived from the literature

\begin{tabular}{ll}
\hline $\begin{array}{l}\text { Sources of Taxonomy of learning } \\
\text { knowledge }\end{array}$ & Definition of the learning category \\
\hline Learning external to the firm & \\
\hline From production Learning by spillovers & $\begin{array}{l}\text { Learning from activities of what competitors and other } \\
\text { horizontally-related firms in the industry are doing }\end{array}$ \\
\hline
\end{tabular}




\begin{tabular}{|c|c|c|}
\hline $\begin{array}{l}\text { From } \\
\text { consumption }\end{array}$ & Learning by interacting & $\begin{array}{l}\text { Learning by actually interacting with upstream suppliers } \\
\text { or downstream customers, users, and with other } \\
\text { firms/organisations in the industry (Lundvall 1988, } \\
\text { 1992c; von Hippel 1988) }\end{array}$ \\
\hline $\begin{array}{l}\text { From search } \\
\text { 'supply' }\end{array}$ & $\begin{array}{l}\text { Learning from advances } \\
\text { in S\&T and education }\end{array}$ & $\begin{array}{l}\text { Absorbing new developments in S\&T, particularly in } \\
\text { close cooperation with suppliers of technology and skills } \\
\text { (e.g. universities, research labs) }\end{array}$ \\
\hline \multicolumn{3}{|c|}{ Learning internal to the firm } \\
\hline \multirow[t]{3}{*}{ From production } & Learning by doing & $\begin{array}{l}\text { Learning through experience associated with production } \\
\text { activity, assumed to be a passive, automatic and costless } \\
\text { learning process (Arrow1962); }\end{array}$ \\
\hline & Learning by imitating & $\begin{array}{l}\text { Learning generated by trying to imitate the existing } \\
\text { processes or products of customers or competitors by } \\
\text { the own efforts of the firm, which is used } \\
\text { interchangeably with learning from rivals (e.g. Geroski } \\
\text { and Mazzucato, 2002); }\end{array}$ \\
\hline & Learning by failing & $\begin{array}{l}\text { Learning from the mistakes and trying not to repeat } \\
\text { them (e.g. Arino and de la Torre, 1998). }\end{array}$ \\
\hline \multirow[t]{2}{*}{$\begin{array}{l}\text { From } \\
\text { consumption }\end{array}$} & Learning by using & $\begin{array}{l}\text { Learning associated with use of what is supplied, e.g., } \\
\text { products, machinery and inputs (Rosenberg 1982); }\end{array}$ \\
\hline & Learning by monitoring & $\begin{array}{l}\text { Learning generated by monitoring what customers and } \\
\text { suppliers are doing in the industry (Sabel 1994) (impact } \\
\text { on quality improvements in product and production } \\
\text { processes) and what competitors are doing in the } \\
\text { industry (impact on imitative effects on products, } \\
\text { marketing, technology, and management) }\end{array}$ \\
\hline \multirow[t]{3}{*}{$\begin{array}{l}\text { From search } \\
\text { 'supply' }\end{array}$} & $\begin{array}{l}\text { Learning from } \\
\text { searching }\end{array}$ & $\begin{array}{l}\text { Learning identified with in-house R\&D activity of the firm } \\
\text { that aims at new knowledge generation, involving } \\
\text { interaction with and learning from technology suppliers } \\
\text { (Nelson and Winter 1982, Dosi 1988); }\end{array}$ \\
\hline & Learning by research & $\begin{array}{l}\text { Knowledge search by an in-house research unit using } \\
\text { scientific and technological means of research to } \\
\text { overcome a problem, to develop a new process or } \\
\text { products, to improve a technique or to teach the newest } \\
\text { information to employees and trainees (e.g. Kim 1998a). }\end{array}$ \\
\hline & $\begin{array}{l}\text { Learning by } \\
\text { training/R\&D }\end{array}$ & $\begin{array}{l}\text { Learning generated through formal search processes } \\
\text { which are in-house R\&D and internal training (von } \\
\text { Tunzelmann and Wang 2007) }\end{array}$ \\
\hline
\end{tabular}

Source: Based on von Tunzelmann and Wang (2007) and Malerba (1992), and the relevant learning literature.

Malerba (1992) systematise the learning mechanisms as external and internal to the firm. To operationalise 'learning in networks', this paper adopts his learning taxonomy with elaborations made by von Tunzelmann and Wang (2007) (see Table 2). His taxonomy is a plausible candidate for overcoming the empirical deficiencies of the upgrading literature with regard to the learning concept and its connection to a variety of networks. Therefore, the observed outcome of each learning mechanism is in one of the upgrading types; product, process, function or managerial activity in the firm.

\subsubsection{Learning from external sources}

The emerging market firms seek help from knowledge spillovers due to their shortcomings in (or lack of) interpersonal relationships, skills, knowledge, and managerial capability (Caves 1999). Knowledge spills over usually through demonstration, observation, imitation and application of processes, advanced technologies, product designs, management practices, and most importantly through 
mobility of trained labour and management personnel which allow the transfer of tacit knowledge (Mowery and Oxley 1995, Kim 1998a, Gunther 2005, Saliola and Zanfei 2009). Recently in the literature, 'spillovers through cooperation' is examined in the context of foreign customer support to domestic suppliers in order domestic firm to produce certain products according to the quality requirements of the foreign customer and to become a reliable future supplier, e.g. in GVCs/GPNs (Gunther 2005). In their empirical work, Lee et al. (2016) find that spillovers from networks of group companies are greater than those from arm's length relations. The literature strongly suggests that collaborative and contract research with universities as well as personal networks of academic and firm researchers in problem-solving or product and process innovation may result in knowledge spillovers (Varga 2000, Audretsch et al. 2004).

Firms learn through interaction with their upstream suppliers or downstream customers, users, and with other firms/organizations in the industry (Lundvall 1992). Such interaction refers to frequent talk and/or close work between individuals or groups. The emerging market literature provides evidence of GVCs/GPNs as an avenue for learning by interacting with foreign partners, mainly customers but sometimes suppliers, who serve as important sources of knowledge for emerging market firms (Bell and Albu 1999, Pellegrin 2001, Schmitz 2004, Fu et al. 2013). Hence, an association between learning by interacting and production networks is more expected than with other learning mechanisms external to the firm.

Linkages between university and industry are another source of learning for firms. These involve learning from new advances in science and technology (S\&T). They take the form of education (postgraduate students), joint or contract research, hiring consultancy services and/or exchanging skilled personnel (e.g. professors), publications, technical meetings with any of these partners, and participation in conferences and symposiums (Teece 1989, Veugelers and Cassiman 1999, Daim and Kocaoglu 2008). Technology acquisition through technology suppliers is another source of accessing new advances in S\&T; mainly because 'package' technology purchases, which provide installation, training and after sale services within the warranty period, have facilitated development of reverse engineering capabilities and have been particularly important in the early stages of the industrialisation in the developing countries (Kim 1980, Dahlman and Fonseca 1987, Mowery and Oxley 1995, Contractor 1998, Radosevic 1999a, Lee 2013). Hence, learning by advances in S\&T seems to be rooted in technology sourcing networks.

\subsubsection{Internalisation of external knowledge}

Firms absorb the new knowledge acquired through their own efforts and in a cumulative way. Internalising externally acquired knowledge can be generated through mechanisms such as learningby-doing (i.e. improving the existing knowledge base, experience and skills in production by means of externally acquired knowledge), through learning-by-imitating (i.e. trying to imitate the existing processes or products of customers or competitors) or through learning-by-failing (i.e. learning from mistakes such as in cooperating with other agents or in meeting the requirements of customers, partners, etc., and trying not to repeat these mistakes).

Firms can internalise new knowledge through acquisition of new technology and its subsequent use (i.e. learning-by-using) or through paying attention to what customers and suppliers (vertical effects, Sabel 1994) and competitors and other firms (horizontal effects - Malerba 1992) are doing in the industry (learning-by-monitoring).

The most active form of internalising externally acquired knowledge is through learning-by-research (Kim 1998a) and learning-by-training (von Tunzelmann and Wang 2007). In the emerging market context, in the early years of transition, these internal learning mechanisms are expected to be 
stimulated and guided by external sources of knowledge, such as networks, and over the years the firms might consciously generate these activities on their own. Such continuum of capability development through learning by training and research helps us understand the changing level of absorptive capacity of the firm. However, it is acknowledged that this is a very crude approach to absorptive capacity within the scope of learning in networks, and hence, this research by no means claims to analyse the absorptive capacity of the firm.

When internal learning mechanisms are concerned, the effective use of learning by doing/imitating/ failing and learning by using/monitoring within the firm are passive approaches to internalisation of external knowledge while that of learning by training and research is a more active approach. The latter type of learning is therefore more representative of a developing absorptive capacity within the emerging market firm.

Absorption of externally acquired knowledge also rely on firms' ability to share and transfer the knowledge of individuals and groups within the organisation. This happens through frequent communication, discussion, experience sharing, observation, teaching, working together closely and socialising activities (Brown and Duguid 1991, Kogut and Zander 1992, Ghoshal et al. 1994, Goh and Richards 1997, Inkpen 1998, Hansen 1999 and 2002, Dutrenit 2000, Brass et al. 2004, BarnerRasmussen and Bjorkman 2005).

Firms "assimilate knowledge all the time at different levels" (Dutrenit 2000: 50), and most of the time unconsciously. Similar to knowledge creation (Nonaka 1994), knowledge sharing within the firm is composed of a spiral of interactions that "starts at the individual level, moves up to the group level, and then to the firm level" (Inkpen 1998: 76). In the context of networks and the reverse learning trajectory of emerging market firms, a spiral of knowledge processing within the firm starts with the inter-organisational knowledge transfer from the partner, moves to the specialised unit level, then to the inter-unit level representing team-work within the firm and finally to the firm level.

Empirically, Hansen (1999) uses inter-unit relations to understand the role of weak ties in sharing knowledge across organisational subunits in the search-transfer problem in MNCs. He defines interunit relations "as regularly occurring informal contacts between groups of people from different operating units in an organisation" (Hansen, 1999: 83). Brass et al. (2004) argue that firm performance and knowledge-related activities within the firm are influenced significantly by the patterns of inter-unit relations. By reviewing the literature, they present interpersonal ties among individuals in different units within the organisation as the most important antecedent for inter-unit relations, while the common antecedent for both interpersonal and inter-unit relations is found in the organisational structure and control mechanisms.

\section{The Research Design}

In research design and analysis, mixed methods is used (Cresswell \& Plano Clark 2007, Greene 2007, Teddlie and Tashakkori 2009), primarily due to the ability of this approach to create connections between difficult-to-measure but richer conceptualisations than quantitative or qualitative research method alone (Tashakkori and Teddlie 2010). More specifically, we used 'concurrent nested' design method ${ }^{4}$ (Creswell 2003): during sample formation and data collection qualitative research methods

\footnotetext{
${ }^{4}$ Concurrent nested design guides the analysis by prioritising one of the research methods over the other (e.g. in this research, quantitative analysis method of multinomial logistic regression is employed as the primary method of analysis) while the other method is embedded or nested in the prioritised primary analysis method (e.g. qualitative research methods serves as the supporting secondary method for data collection). This way, it allows us to retrieve information from different levels.
} 
were employed, while quantitative methods were used in the analysis after data transformation (see Table 3).

\subsection{The sample and data collection}

During the transition years, the industrial structure of Poland was characterised by a few large domestic firms and traditional industries (OECD 2007). Moreover, at that time in Central Europe, incumbent big firms were both major players in the economy and the key nodes in GPNs/GVCs after the transformation (Pickles and Smith 2011), and yet these firms had in general received less attention than multinational companies (Szymanski et al. 2007). Therefore, this research aimed to study large domestically-owned firms with more than 500 employees.

The sample was based on a compilation to firm database composed of 78 food-processing and 46 clothing Polish-owned firms using the accessible listing of firms registered with Polish Embassy in London. ${ }^{5}$ The final sample was designed around 16 large Polish-owned firms: eight in the foodprocessing industry, representing $10 \%$ of the population of large food-processing firms and eight in the clothing industry, $17 \%$ of the population of large clothing firms.

Different from previous upgrading studies, this sample consists of firms that operate in a wide range of multiple chains and networks, such as OEM and ODM for foreign customers, OBM in Polish market and OEM/ODM for network organisers and retailers in the Polish market ${ }^{6}$ as well as getting involved in knowledge networks. In both industries, all the firms studied are large brand manufacturers at home, operate in market niches that they were restricted to in the socialist era and have largely stayed in these markets during the transition years. Some of the food-processing firms function as subcontractors to foreign customers at home, while some export their own products to Europe, US and other parts of the world. The extent of their exports ranges between 1-5\% of sales for four of them and $11-25 \%$ for the other four. All the clothing firms function as subcontractors to foreign customers abroad, and this output accounts for $60-90 \%$ of the production of six of them, while the other two firms report $25-50 \%$ and below $25 \%$ of their production respectively. None of them have exports of their own products. There is a similar pattern in firms' network size and network density in both of the industries studied, strengthening the results of our analysis with regard to their comparison (Table A.1).

A possible limitation of the sampling design was that the data encompass only two industries. Because they are representing low and medium-technology (LMT) industries, a pooled sample of data from these industries is not expected to create bias in the interpretation of the results for the LMT industries.

The unit of analysis is 'dyadic links' in a given network (Johanson and Mattson 1987, Anderson et al. 1994, Hite and Hesterly 2001). Each dyadic link has its own nature, depth and frequency, varying with respect to knowledge transfer possibilities, and therefore, capturing the nature of learning

\footnotetext{
${ }^{5}$ www.polishemb-trade.co.uk/Home en/Main en.htm (accessed in October-November 2000). There was no available online resource for the complete register of all firms in these industries in Poland at the time.

${ }^{6}$ This is because the industries examined in this paper are part of the buyer-driven GVCs, if we refer to the original distinction between buyer- and producer-driven GVCs made by Gereffi (1994). The buyer-driven GVCs emerge from tradeled industrialisation in labour-intensive consumer goods industries and are essentially governed by large retailers, brandname manufacturers and marketers as well as trading companies. Brand-name manufacturers enforce their product specifications on local suppliers (making them OEM producers), but large retailers and marketers are not involved in the production process at all (making local suppliers ODM producers). Hence, the local suppliers are exposed to a mix of governance modes (regarding the typology of GVC/GPN governance by Gereffi et al. (2005)) in different GVCs/GPNs (Gereffi and Lee 2012).
} 
processes within these links empirically requires an in-depth analysis (Lyles 1988, Figueiredo 2010). The primary data was collected through face-to-face semi-structured interviews during two a-month visits to Poland in May and November 2001, which is increasing the strength and novelty of analysis in this paper. During the interviews, a set series of questions is used as a structured guide. The content of the interview questions focussed on detailing the particularity of each dyadic link of the firm and the learning that occurred in that link, as explained below when discussing each variable. Instead of forcing the interviewees to remember relationships unprompted or asking about the types of relationships directly (e.g., "what are your market-based relationships? Or does your firm have any arm's length relationships?"), relationships with specific types of partners were asked about. As the details of one particular relationship were elaborated through a variety of questions, the interviewees recalled other relevant relationships. The pre-determined list of partners investigated consists of i) technology and raw material suppliers, ii) customers / buyers / end-user firms, iii) downstream distributors / users / other actors, iv) competitor and complementary firms in the industry, v) universities, public or private research institutes / laboratories, vi) consultants, consulting firms, export / intermediary agencies, design agencies, human resource or advertising agencies, vii) Chamber of Commerce or industrial organizations/associations, governmental institutions. The final networks data involved formal and informal relationships.

Thirty-one semi-structured interviews with the core firms and nineteen open-ended interviews with ten public and private organizations were conducted (such as researchers in the public and private research institutions, academics at the universities in food-processing and textile and clothing departments, and people in organisations such as Chamber of Commerce, accreditation organisations, and statistical institutes), some of which were partners declared by the interviewed firms (see Table A.2). As many as four leading individuals who were responsible for and knowledgeable of the current and past collaborative experiences of the firm were interviewed in a given firm, such as top and middle level managers (ranging from general managers to production managers, marketing managers, purchasing managers, quality assurance managers and finance managers). They were interviewed either separately (one-to-one interviews with only one person) or in groups (with two or more people with similar qualifications in their specialisation or in different fields of activity). ${ }^{7}$ A third category of 'spin-off' interviews took place when the right managers were called in by the main interviewee to provide me with the correct information. Out of 50 interviews, the majority of the interviews were one-to-one (34). Only 11 were group interviews, and 5 were spin-offs (see Table A.2).

In order to minimise the possibility of common method bias and to increase the reliability of results, multiple informants (Lyles 1988) and double-checking were used as much as possible through lots of elaborations and repetitions of the same question in different styles during the interviews. Each firm interview took at least four hours. In each firm, the production site was observed and structured conversations with operational managers, production chiefs, senior and junior engineers were conducted. They proved to be a useful technique of double-checking the information received from top/middle-level managers. After the interviews, the revealed links were double-checked through a thorough mining of available documentary sources, such as Polish and foreign newspapers, journals and business magazines; online research, contacting the partner in question, as well as documents obtained from the interviewed firms such as company annual reports, previously prepared documents on the history of the firms, product catalogues and documents prepared by the personnel. I also gathered Polish official data on ISO and HACCP certificates. ${ }^{8}$ The interviews with

\footnotetext{
7 Group interviews are considered as one interview.

${ }^{8}$ ISO 9000/14000 certificates are quality assurance standards set by the International Standards Organisation. HACCP system refers to Hazard Analysis and Critical Control Point and aims at ensuring food safety by assessing hazards and setting up control mechanisms throughout the production process from handling of raw material to finished product and is particularly important in the food-processing industry.
} 
other organisations collected information about their activities in the industry, about the past and present of the relationships between these organisations and the firms, and about their views on the state of the industry as well as the changes in the respective industry throughout transition. All these efforts were to triangulate multiple sources of the same evidence and ensured data reliability.

Finally, based on the content analysis of the interviews and subsequent coding through analytical iterations to ensure data reliability, an original dataset composed of 467 dyadic links of 16 large domestically-owned food-processing and clothing firms in the transition period (1989-2001) was constructed. Another possible limitation of sample bias due to small response rate was eliminated by this sizeable sample of network data that incorporated the depth and diversity of information collected on networking activity by each firm into the analysis.

\subsection{Variable definition and operationalization}

Dependent variable. The dependent variable is 'types of firm-level upgrading'. It is based on the upgrading typology of Humphrey and Schmitz (2004); its categories are process upgrading, product upgrading, functional upgrading and managerial upgrading. This typology enables us to observe the incremental effects of knowledge processing within the firm and is suitable for statistical analyses.

Its operationalization is based both on our observations during fieldwork and on the insights from earlier empirical work (see Table A.3). Questions were asked according to the definitions of new product and processes determined earlier on the basis of previous empirical work and as relevant to the studied industries. The category of no upgrading through the relationship was observed and substantiated the argument that being inserted into a GVC (or network) does not necessarily enable or guarantee upgrading (Navas-Aleman 2006).

This variable does not rely on the evaluation of the interviewees; it is not a perceptual variable but an objective variable based on the outcomes that were present or about to happen. Statements by the interviewees regarding the contribution by any of the firm's relationships to any of the upgrading types were corroborated through actual observations during the fieldwork. The firms interviewed were asked questions whether the relationship contributed to a change/improvement in the firm's products, processes, other operations, and if so, what in particular the relationship with a specific partner improved in the firm, such as management, technology and product development, production, marketing and distribution, design, logistics, and so on.

Independent variables. The independent variables are 'external learning mechanisms' (EXTLEARN) and internal factors complementary to external learning mechanisms, which are composed of 'internal learning mechanisms' (INTLEARN) and 'knowledge sharing levels within the firm' (KNOWSHARE). In addition to these independent variables, the other regressors used in the models are INDUSTRY and time PERIOD (see Table 3).

Table 3. Variables used in the analysis

\begin{tabular}{llll}
\hline & Variable name & Variable code & Description of its categories \\
\hline Dependent & Types of firm-level & UPGTYPE & If there is \\
variable & upgrading & 1 managerial upgrading \\
& & 2 process upgrading \\
& & 3 product upgrading \\
& & 4 functional upgrading \\
& & 5 no upgrading \\
\hline Independent & External learning & EXTLEARN & If the relationship leads to \\
variables & mechanisms & & 1 learning from knowledge spillovers \\
& & 2 learning from advances in S\&T and education \\
& & 3 learning by interacting \\
\hline
\end{tabular}




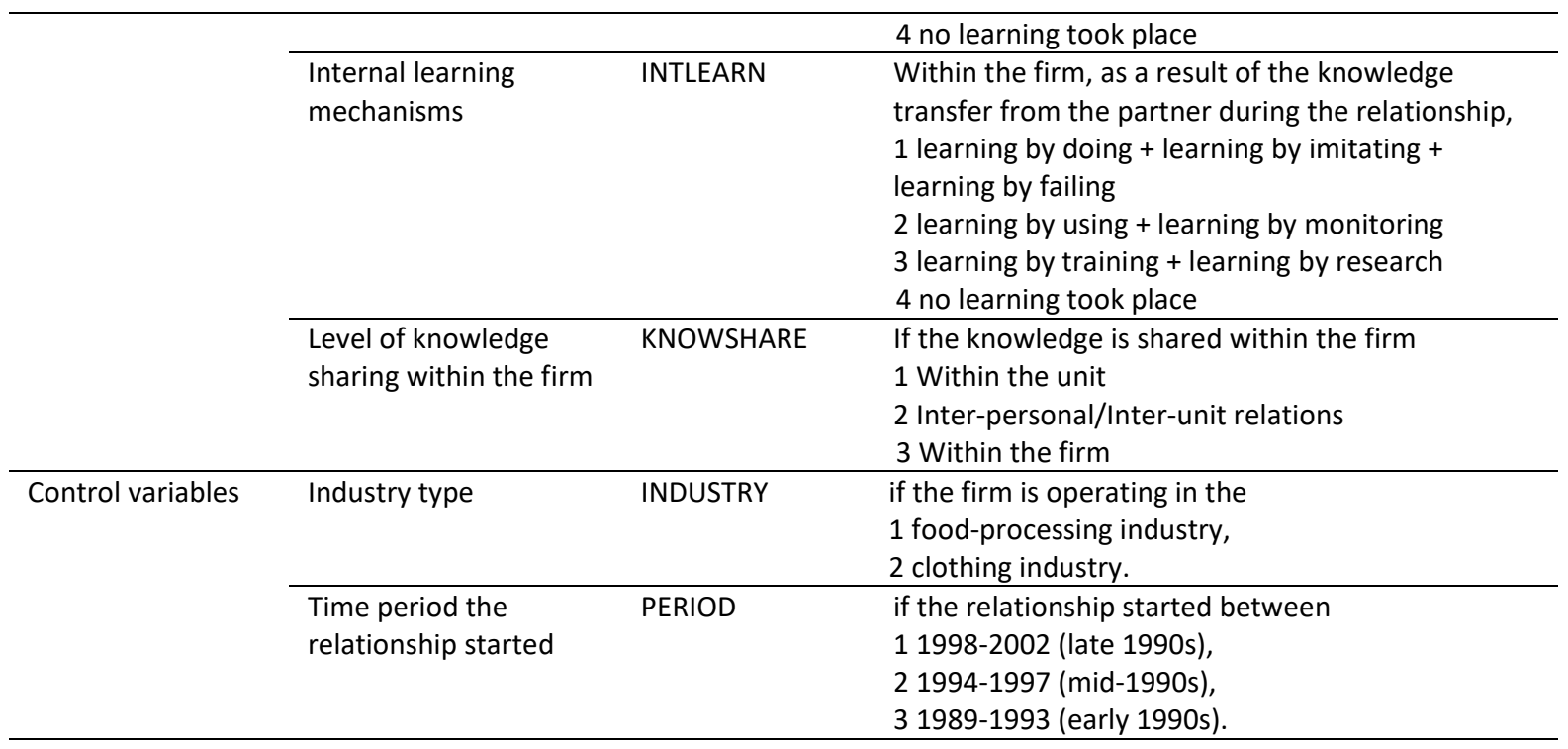

The elaborations on the stories of the relationships with the interviewees and the observations throughout the interview revealed how the firm learned during that relationship and enabled us to process the retrieved information into the appropriate learning mechanism used during the relationship (Table 7).

External learning mechanisms. EXTLEARN represents learning whilst in a relationship and draws on the taxonomy of Malerba (1992). It is a categorical variable which is relationship-specific and incremental in nature. It has four categories: learning from knowledge spillovers, learning from advances in S\&T and education, learning by interacting, and no learning.

This variable was built through a thorough understanding of under which conditions and in which ways knowledge was transferred during a relationship, how the firm distinguished the importance of this external knowledge and used it for building capabilities and competences.

The interviewees were directly asked about whether their firm learned anything new during a particular relationship with a specific partner, and if so, what was it that they did not know before. Then we elaborated the answer with a variety of questions on the level, context, content and means of the interaction among people in that particular relationship that led to knowledge transfer (e.g., face-to-face meetings, training provided between partners, the extent of observation and demonstration, the content of knowledge acquired, if and how this knowledge is shared and/or used within the firm).

Having access to an external source does not necessarily mean the firm is capable of recognizing new, valuable knowledge. The (in)ability of the interviewee to elucidate the contribution of the new knowledge acquired in the relationship to the firm substantiated the presence of learning in networks. There was either a conscious awareness of the alternatives that the new knowledge provides the firm (Nicolini and Meznar 1995) or no new valuable knowledge for the firm to be withdrawn during the relationship (i.e. no learning during the relationship). Presence of such ability constituted an assurance that learning was happening in some particular way that was unique to that relationship and its dynamics. When existed, learning resulted in a concrete outcome, which was proudly presented during the interview in the form of a modified/new (to the firm) product or process technology, organisational or managerial routine or a completely new skill or function within the firm. 
To exemplify how the coding is done for the learning categories, we can take the example of a relationship between a global buyer and a Polish clothing supplier. The global buyer demands the Polish supplier to purchase a special interlining machine that makes the product look like handmade. This is a new knowledge/technology that Polish supplier had never heard of. Additionally, the global buyer tells where to buy it or gives choices about where to buy. Both pieces of information -about the machine and about where to buy it - are knowledge spillovers. The process of the technology purchase through arm's length relations with the technology supplier and the associated technical training is learning from advances in S\&T. Once the new machinery is bought, the global buyer brings in the new product designs that are prepared to be sewn with this new technology. The Polish supplier not only gains new skills in using this new machine and perhaps becomes the first in its market to use and excel at it, but also is introduced to a completely new product design (with a new process technology) that can be imitated for its own brand in the domestic market. The former is learning by interacting and the latter is learning from spillovers if the firm engages in imitating. Demonstrative observations for each external learning mechanism from this research are presented in Table A.4.

Internal learning mechanisms. INTLEARN does not refer to creation of knowledge by internal sources of the firm, but to the adoption, and adaption of, externally acquired knowledge using internal mechanisms to upgrade some functions of the firm.

The firms interviewed were asked to detail the process of how the externally acquired knowledge had been processed within the firm: whether the new knowledge was used within the routine practices of the firm, or applied into existing production processes to turn it into a concrete idea, new practice, routine or some sort of by-product within the firm. We extended the latter to identify any firm capability to conduct search and research activities as a result of such application of the new knowledge within the firm. We also enquired whether the firm conducted special training to its employees itself or through some external agents to teach the new practices or knowledge the firm acquired. Table A.5 presents demonstrative observations from this research for each category.

Knowledge sharing within the firm. KNOWSHARE serves to understand at what levels of the firm the externally acquired knowledge is processed within the firm. Knowledge could be shared among employees of a unit (i.e. within a unit); among individuals or groups of people from different units (i.e. inter-personal / inter- unit) ${ }^{9}$, or at all levels of the firm by means of top or middle management sharing with everybody (i.e. within the firm). The interactions may be realised formally or informally; except in all levels of the firm; this is almost always formal.

The firms interviewed were asked who in the firm shared the externally acquired knowledge and how. The purpose was to understand the groupings between the individuals, units, and the special arrangements that bring people together such as teamwork, workshops, and seminars. One example concerned an engineer who acquired certain knowledge on the process technology from the technology supplier, developed an idea, discussed it with the production and marketing manager in detail, and was given permission to try his idea with the help of a team composed of engineers, product design and brand managers, leading - after a few trials - to the development of a new product.

Control variables. 'Industry' is a meso-level indicator of heterogeneity, comparing medium-tech food-processing industry with low-tech clothing industry. 'Time period' is an indicator of dynamic analysis over three time periods composed of 1989-1993 (early 1990s), 1994-1997 (mid-1990s) and

\footnotetext{
${ }^{9}$ Based on the findings of Brass et al. (2004) in section2.4.2, the two of them are categorised under one category.
} 
1998-2001 (late 1990s) with the purpose of identifying any emerging patterns in the use of external learning mechanisms by the emerging market LMT firms in their relationships.

The firm characteristics were implicitly contained in the definition of the sample; hence, they were not inserted as a set of constructs into the analysis. The characteristics of the firms chosen in our sample allow us to distinguish the firms studied from SMEs and start-ups (i.e. firm size) as well as from firms with no inheritance of a strong, reputable brand that is associated with a high level of production capability accumulation (but no R\&D) in both industries.

\subsection{Model specification}

Multinomial logistic regression (MLR) was employed as a statistical method due to the use of a dataset with categorical variables that are composed of two or more categories with no intrinsic ordering to these categories. MLR allows us to determine characteristics that differentiate and/or are common in different groups (Hosmer and Lemeshow 2000, Borooah 2002, Greene 2003, Tabatchnick \& Fidell, 2007, Petrucci 2009). Its major difference from linear regression is the use of predicted probabilities in the interpretation of estimates (odds-ratios), since the dependent variable is now a probability (Winkelmann and Winkelmann 1997). Also, because the dependent variable in this research has four unordered categories and its normality assumption cannot be reasonably assumed, MLR becomes the most suitable statistical method of analysis. ${ }^{10}$ In model building, the strategies suggested by Hosmer and Lemeshow (2000) and Tabatchnik and Fidell (2007) were strictly followed.

In accordance with the operationalisation of learning in networks in two stages, two upgrading models (UMs) were specified: we first examine the main effects of the contribution of external learning mechanisms on types of firm-level upgrading (Model 1 ) to find out which external learning mechanisms contribute to firm-level upgrading. Then the combined effect of these mechanisms with the knowledge internalisation variables on types of firm-level upgrading (Model 2) to find out how internal factors complement external learning in contributing to firm-level upgrading. Particular interest in the second MLR analysis was in finding out the extent of the mediating effect of internal factors complementary to the external learning mechanisms on the firm-level upgrading types, since without these factors learning in networks would have little chance to turn into upgrading within the firm. Estimations were carried out using the full sample.

Model 1 (with external learning mechanisms only): The log odds-ratio is $\alpha_{j 0}$ for a relationship that leads to no learning externally. $\beta_{\mathrm{jk}}$ measure the degree of external learning mechanisms with respect to the types of firm-level upgrading.

$\log (\operatorname{Prob}($ UPGTYPE $=\mathrm{j}) / \operatorname{Prob}($ UPGTYPE $=5))=\alpha_{\mathrm{j} 0}+\beta_{\mathrm{j} 1}$ EXTLEARN $+\theta_{\mathrm{j} 1}$ INDUSTRY $+\theta_{\mathrm{j} 2}$ PERIOD

Model 2 (i.e. with knowledge internalisation variables): The log odds-ratio is $\alpha_{j 0}$ for a relationship that leads to no learning both externally and internally though there is knowledge sharing at all the levels of the firm. $\beta_{\mathrm{jk}}$ measure the degree of learning mechanisms in networks external and internal to the firm with respect to the types of firm-level upgrading.

$\log \left(\operatorname{Prob}(\right.$ UPGTYPE=j) $/$ Prob $($ UPGTYPE $=5))=\alpha_{\mathrm{j} 0}+\beta_{\mathrm{j} 1}$ EXTLEARN $+\beta_{\mathrm{j} 2}$ INTLEARN $+\beta_{\mathrm{j} 3}$ SHARING +

\footnotetext{
${ }^{10}$ Compared to linear regression, logistic regression makes no assumption about the distribution of the independent variables (e.g., for them to be normally distributed, linearly related or of equal variance within each group). As a result, the relationship between the dependent and independent variables is not a linear function but a logit transformation.
} 
In both models, $\theta_{\mathrm{jk}}$ assesses industry and temporal effects.

The log-odds ratios of these probabilities in each model will yield four logit functions; each comparing the probability of a type of upgrading to the probability of no upgrading (i.e. the reference outcome).

logit 1: $\log [\operatorname{Pr}$ (managerial upgrading)/Pr (no upgrading)]

logit 2: $\log [\operatorname{Pr}$ (process upgrading)/Pr (no upgrading)]

logit 3: $\log [\operatorname{Pr}$ (product upgrading)/Pr (no upgrading)]

logit4: log [Pr (functional upgrading)/Pr (no upgrading)]

\section{Estimation results}

An important result is related to the statistically significant effect of different time periods during transition years on the likelihood of different types of firm-level upgrading; letting us capture the over-time change, hence a dynamic analysis of firm-level upgrading.

\subsection{Descriptive statistics}

When the variables are categorical, descriptive statistics are largely limited to cross-tabulations and chi-square tests of independence (Table 4). ${ }^{11}$ All variables used in both models are statistically significant at $1 \%$ level, except INTLEARN (at $5 \%$ level for all firms), and are associated with the industry type. The contribution of the relationships is focused more on process and functional upgrading in both industries, with the contribution to product upgrading in the clothing firms twice as great as in the food-processing firms (17\% vs. $8 \%$ ) and contribution to managerial upgrading significantly greater in food-processing firms than in clothing firms ( $23 \% \mathrm{vs.} 10 \%)$.

One sixth to one fifth of the relationships in the food-processing and clothing firms respectively make no contribution to firm-level upgrading. Both EXTLEARN and INTLEARN are fairly equally distributed in the dataset. The distribution of food-processing firms' relationships by EXTLEARN is similar to that of total relations, with significance attributed to learning from advances in S\&T and education (34.4\%). Majority of learning in clothing firms' relationships occurs by interacting in $40.8 \%$ of the relationships. Surprisingly, no learning happened in slightly more relationships (18\%) of clothing firms than learning from advances in S\&T (15.4\%). Polish food-processing firms internalise the externally acquired knowledge mostly by means of 'learning by using + monitoring' (32.8\%) and 'learning by training + research' (31.8\%). Clothing firms, on the other hand, focus on 'learning by doing + imitating + failing' (32.7\%). Internal learning does not take place approximately in one-fifth $(20 \%)$ of total relations and of the relations of both industries. KNOWSHARE significantly differ between the two industries; with emphasis on more "specialised" intra-unit knowledge sharing in the food-processing firms and on more "teamwork-oriented" inter-personal/ inter-unit knowledge sharing in the clothing firms.

\subsection{Model 1}

\footnotetext{
${ }^{11}$ Moreover, univariate analysis of each variable against the dependent variable showed statistically significant association (at $1 \%$ level) between tested variables and confirmed that all the variables met the criterion to be used in the multivariate model (i.e. $p$-value $<0.25$, Hosmer and Lemeshow 2000) (see Table A.6).
} 
The estimation results of Model 1 suggest that there is strong evidence that external learning mechanisms are important and influential factors that change the odds of types of firm-level upgrading (Table 5). 
Table 4. Descriptive Statistics

Industry type (INDUSTRY)

\begin{tabular}{|c|c|c|c|c|c|c|c|c|c|}
\hline \multirow{2}{*}{\multicolumn{3}{|c|}{ Total relationships }} & \multirow{2}{*}{\multicolumn{3}{|c|}{$\begin{array}{l}\text { Relationships of food-processing } \\
\text { firms }\end{array}$}} & \multirow{2}{*}{\multicolumn{3}{|c|}{ Relationships of clothing firms }} & \multirow[b]{3}{*}{$\begin{array}{l}\text { Pearson } \\
\text { Chi-square } \\
\text { test } \\
\text { (Asymp.Sig.) } \\
\text { INDUSTRY } \\
\text { TYPE vs } \\
\text { (VARIABLE) } \\
\end{array}$} \\
\hline & & & & & & & & & \\
\hline count & $\%$ & $\begin{array}{l}\text { Chi- } \\
\text { square } \\
\text { test } \\
\text { (Asymp. } \\
\text { Sig.) }\end{array}$ & count & $\%$ & $\begin{array}{l}\text { Chi- } \\
\text { square } \\
\text { test } \\
\text { (Asymp. } \\
\text { Sig.) }\end{array}$ & count & $\%$ & $\begin{array}{l}\text { Chi- } \\
\text { square } \\
\text { test } \\
\text { (Asymp. } \\
\text { Sig.) }\end{array}$ & \\
\hline \multirow[t]{2}{*}{467} & 100 & & 195 & 41.8 & & 272 & 58.2 & & \\
\hline & & $0.000^{* * *}$ & & & $0.000^{* * *}$ & & & $0.000^{* * *}$ & $0.025^{* * *}$ \\
\hline 262 & 56.1 & & 117 & 60.0 & & 145 & 53.3 & & \\
\hline 132 & 28.3 & & 58 & 29.7 & & 74 & 27.2 & & \\
\hline \multirow[t]{2}{*}{73} & 15.6 & & 20 & 10.3 & & 53 & 19.5 & & \\
\hline & & $0.000^{* * *}$ & & & $0.000^{* * *}$ & & & $0.000^{* * *}$ & $0.000^{* * *}$ \\
\hline 125 & 26.8 & & 55 & 28.2 & & 70 & 25.7 & & \\
\hline 109 & 23.3 & & 67 & 34.4 & & 42 & 15.4 & & \\
\hline 157 & 33.6 & & 46 & 23.6 & & 111 & 40.8 & & \\
\hline \multirow[t]{2}{*}{76} & 16.3 & & 27 & 13.8 & & 49 & 18.0 & & \\
\hline & & $0.044 * * *$ & & & $0.000^{* * *}$ & & & $0.009 * * *$ & $0.000^{* * *}$ \\
\hline 116 & 24.8 & & 27 & 13.8 & & 89 & 32.7 & & \\
\hline
\end{tabular}

\begin{tabular}{|c|c|c|c|c|c|c|c|c|c|c|}
\hline Sample size & 467 & 100 & & 195 & 41.8 & & 272 & 58.2 & & \\
\hline Time period (PERIOD) & & & $0.000 * * *$ & & & $0.000 * * *$ & & & $0.000 * * *$ & $0.025 * * *$ \\
\hline - late 1990s/early 2000s & 262 & 56.1 & & 117 & 60.0 & & 145 & 53.3 & & \\
\hline - mid-1990s & 132 & 28.3 & & 58 & 29.7 & & 74 & 27.2 & & \\
\hline - early 1990s & 73 & 15.6 & & 20 & 10.3 & & 53 & 19.5 & & \\
\hline Learning external to the firm (EXTLEARN) & & & $0.000 * * *$ & & & $0.000 * * *$ & & & $0.000 * * *$ & $0.000 * * *$ \\
\hline - learning from knowledge spillovers & 125 & 26.8 & & 55 & 28.2 & & 70 & 25.7 & & \\
\hline - learning from advances in S\&T & 109 & 23.3 & & 67 & 34.4 & & 42 & 15.4 & & \\
\hline - learning by interacting & 157 & 33.6 & & 46 & 23.6 & & 111 & 40.8 & & \\
\hline - no learning / no awareness of learning & 76 & 16.3 & & 27 & 13.8 & & 49 & 18.0 & & \\
\hline Learning internal to the firm (INTLEARN) & & & $0.044 * * *$ & & & $0.000 * * *$ & & & $0.009 * * *$ & $0.000 * * *$ \\
\hline $\begin{array}{l}\text { - learning by doing + learning by } \\
\text { imitating+ learning by failing }\end{array}$ & 116 & 24.8 & & 27 & 13.8 & & 89 & 32.7 & & \\
\hline $\begin{array}{l}\text { - learning by using + learning by } \\
\text { monitoring }\end{array}$ & 128 & 27.4 & & 64 & 32.8 & & 64 & 23.5 & & \\
\hline $\begin{array}{l}\text { - learning by training and learning by } \\
\text { research }\end{array}$ & 131 & 28.1 & & 62 & 31.8 & & 69 & 25.4 & & \\
\hline - no learning / no awareness of learning & 92 & 19.7 & & 42 & 21.5 & & 50 & 18.4 & & \\
\hline \multicolumn{3}{|c|}{ Level of knowledge sharing within the frim (KNOWSHARE) } & $0.000 * * *$ & & & $0.000 * * *$ & & & $0.000 * * *$ & $0.000 * * *$ \\
\hline - within the firms & 81 & 17.3 & & 53 & 27.2 & & 28 & 10.3 & & \\
\hline \multicolumn{11}{|l|}{ Dependent variable } \\
\hline Types of Firm-level Upgrading (UPGTYPE) & & & $0.000 * * *$ & & & $0.000 * * *$ & & & $0.000 * * *$ & $0.000 * * *$ \\
\hline - process upgrading & 72 & 15.4 & & 45 & 23.1 & & 27 & 9.9 & & \\
\hline - product upgrading & 128 & 27.4 & & 60 & 30.8 & & 68 & 25.0 & & \\
\hline - managerial upgrading & 62 & 13.3 & & 16 & 8.2 & & 46 & 16.9 & & \\
\hline - functional upgrading & 122 & 26.1 & & 43 & 22.1 & & 79 & 29.0 & & \\
\hline - no upgrading & 83 & 17.8 & & 31 & 15.9 & & 52 & 19.1 & & \\
\hline
\end{tabular}

Source: Own dataset, SPSS version 17 
- Learning from knowledge spillovers during a relationship contributes mostly to product upgrading and to some extent to functional upgrading.

- Learning from advances in $S \& T$ during a relationship contributes to process and product upgrading.

- Learning by interacting during a relationship contributes to product and functional upgrading while withholds managerial upgrading.

- Managerial upgrading is more likely to occur in food-processing firms, and product upgrading in clothing firms.

- The association of 'the links that started in the late 1990s' compared to those of in early 1990 s is strongest with managerial and functional upgrading.

Process upgrading. The odds of process upgrading occurring through learning from advances in S\&T and education during a relationship is seventeen times greater compared to no learning than the odds of no upgrading. Firms are likely to learn for their process upgrading in the links that started in the early-1990s three times more than those started in the mid-1990s and twice more than those started in the late 1990s.

Product upgrading. All three external learning mechanisms contribute to product upgrading irrespective of time. The odds of product upgrading through learning from advances in S\&T and education and through learning from knowledge spillovers are eleven times greater, and the odds of product upgrading through learning by interacting six times greater compared to no learning in the link than the odds of no upgrading. Polish clothing firms are twice more likely to achieve product upgrading than Polish food-processing firms.

Managerial upgrading. Polish food-processing firms are twice more likely to achieve managerial upgrading than Polish clothing firms (INDUSTRY). Firms are likely to learn for their managerial upgrading from their links that started in the late 1990s seven times more than from those started in early 1990s (PERIOD). The likelihood of a contribution to managerial upgrading by learning by interacting is one-fourth $(0.25)$ as likely as no learning taking place during the relationship.

Functional upgrading. The odds of a link contributing to functional upgrading within the firm through learning by interacting and learning from knowledge spillovers during that relationship are three times and twice greater, respectively, when compared to no learning in that relationship than the odds of no upgrading. Links that started in the late 1990s are twice more likely to contribute to functional upgrading than links that started in the early 1990 s.

\subsection{Model 2}

The complementarity between external learning mechanisms and knowledge internalisation variables (i.e. INTLEARN and SHARING) hints a correlation between all three variables. Table A.7 confirms the strong association between them. Can the knowledge internalisation variables be mediators between external learning mechanisms and the types of firm-level upgrading? Model 2 checks the predictive ability of internalisation variables on the types of firm-level upgrading after adjusting for the differences in external learning mechanisms. 
Table 5. Estimation results of multinomial logistic regression for Model 1

Model 1

\begin{tabular}{|c|c|c|c|c|}
\hline \multirow[b]{2}{*}{ Variables } & \\
\hline & Process upgrading & Product upgrading & Managerial upgrading & Functional upgrading \\
\hline \multirow[t]{2}{*}{ Constant } & 0.06 & $-1.77^{* *}$ & $-2.09 * * *$ & -0.73 \\
\hline & $(0.44)$ & $(0.71)$ & $(0.80)$ & $(0.47)$ \\
\hline \multirow[t]{2}{*}{ food-processing vs clothing industry } & 0.00 & $-0.68 *$ & $0.73 * *$ & -0.05 \\
\hline & $(0.32)$ & $(0.38)$ & $(0.35)$ & $(0.31)$ \\
\hline \multicolumn{5}{|l|}{ Time period } \\
\hline late 1990s (1998-2001) & $-0.71 *$ & -0.07 & $1.95^{* *}$ & $0.71^{*}$ \\
\hline vs early 1990s (1989-1993) & $(0.41)$ & $(0.47)$ & $(0.79)$ & $(0.42)$ \\
\hline mid-1990s (1994-1997) & $-1.12 * *$ & -0.32 & 1.27 & 0.08 \\
\hline vs early 1990s (1989-1993) & $(0.44)$ & $(0.51)$ & $(0.82)$ & $(0.46)$ \\
\hline \multicolumn{5}{|l|}{ External learning mechanisms } \\
\hline learning from knowledge spillovers vs & 0.73 & $2.39 * * *$ & 0.44 & $0.79 *$ \\
\hline no learning & $(0.47)$ & $(0.69)$ & $(0.44)$ & $(0.43)$ \\
\hline learning from advances in S\&T and & $2.84 * * *$ & $2.41 * * *$ & 0.86 & 0.00 \\
\hline education & $(0.52)$ & $(0.79)$ & $(0.54)$ & $(0.64)$ \\
\hline \multicolumn{5}{|l|}{ vs no learning } \\
\hline learning by interacting & 0.40 & $1.84 * * *$ & $-1.41 * *$ & $1.10 * * *$ \\
\hline vs no learning & $(0.43)$ & $(0.67)$ & $(0.55)$ & $(0.39)$ \\
\hline No of observations & 467 & Prob $>$ Chi-Square & 0.000 & \\
\hline Log Likelihood & -148.542 & Psuedo $\mathrm{R}^{2}$ (McFadden) & 0.128 & \\
\hline LR Chi-Square & 187.441 & Correct Classification & $43.9 \%$ & \\
\hline Degrees of freedom & 24 & Reference outcome & No upgrading & \\
\hline Variable Selection Method used & $\begin{array}{c}\text { Stepwise (backward } \\
\text { elimination) }\end{array}$ & Variable removed & None & \\
\hline
\end{tabular}

Source: Own dataset, SPSS version 17.0 
When we tested internalisation variables for mediation (Tables A.8-A.10), the first regressions showed that EXTLEARN affect both INTLEARN and KNOWSHARE (Tables A.8 and A.9 respectively). The second regression showed that EXTLEARN affect UGTYPE (same as Model 1). The third regressions showed that INTLEARN affect UPGTYPE, and lowered the effects of EXTLEARN on UPGTYPE compared to the second regression results (Table A.9). The third regressions also showed that KNOWSHARE affect UPGTYPE, though not as strongly as INTLEARN; and the effects of EXTLEARN on UPGTYPE do not reduce compared to the second regression results. Therefore, we found that internal learning mechanisms constitute a powerful mediator between external learning mechanisms and types of firm-level upgrading, while knowledge sharing levels within the firm do not, and should simply be treated as an independent variable.

After ascertaining the mediating role of INTLEARN, we run the Model 2 (Table 6). Comparison of loglikelihood ratios for Model 1 and Model 2 showed statistically significant improvement with the addition of internalisation variables $\left(\chi^{2}(16,467)=208.24, p<0.001\right)$, indicating that they reliably predict contribution of relationships to upgrading types. There are no inordinately large parameters or standard errors, no indication for a possibility of a problem of empty cells or evidence for multicollinearity in Model 2 (Hosmer and Lemeshow 2000, Tabachnick and Fidell 2007). The INDUSTRY variable was eliminated by the stepwise selection method. Time period, however, is a significant factor, allowing us to observe the effects of change over time on the probability of different types of firm-level upgrading.

Process upgrading. Similar to the results of Model 1, time PERIOD is a significant factor that explains the process upgrading (at $5 \%$ level), and learning from advances in S\&T and education is the sole significant external learning mechanism contributing to process upgrading within the firm. The presence of the mediating effect is understood not only by the reduction in the effect of learning from advances in S\&T and education on process upgrading from 17.04 (odds ratio in Model 1) to 13.65 (odds ratio in Model 2), but also with the significant positive effects of learning by training and research (at $5 \%$ level) and of knowledge sharing within the unit (at $1 \%$ level) and among people and different units within the firm (at $10 \%$ level) on process upgrading. This finding implies that the LMT firm cannot simply be labelled as a 'user' of the technology purchased. Engineering and production capability is exploited not only for the use of the new technology, but re-configurations or modifications of the new technology for in-house applications are done by putting effort into understanding and codifying the tacit components of it. In this sense, learning from advances in S\&T and education seems to be complemented with internal factors that lead to efforts within the firm for technological capability development in Polish food-processing and clothing firms (albeit more in the form of product design and development than R\&D), and not just a substitute for in-house R\&D (Radosevic 1999a).

Product upgrading. Time PERIOD continues to have no significant effect on product upgrading. External learning mechanisms are still significant factors that affect the odds of product upgrading within the firm (at 1\% significance level); however, there is a reduction in the odds ratios of learning from knowledge spillovers (from 10.9 in Model 1 to 7 in Model 2) and of learning from advances in S\&T (from 11.1 in Model 1 to 9 in Model 2), while the significance of learning by interacting disappears altogether. Particularly, links that lead to learning by training and research and learning by doing, imitating and failing are almost 15 and 9 times more likely, respectively, to contribute to product upgrading, and are robust mediators between all external learning mechanisms and product upgrading. KNOWSHARE has no significant effect on product upgrading. 
Table 6. Estimation results of multinomial logistic regression for Model 2

Model 2

\begin{tabular}{|c|c|c|c|c|}
\hline \multirow[b]{2}{*}{ Variables } & \\
\hline & Process upgrading & Product upgrading & Managerial upgrading & Functional upgrading \\
\hline \multirow[t]{2}{*}{ Constant } & -1.68 & $-3.49 * * *$ & $-1.73^{*}$ & $-1.08^{*}$ \\
\hline & $(0.71)$ & $(0.96)$ & $(0.96)$ & $(0.64)$ \\
\hline \multicolumn{5}{|l|}{ Time period } \\
\hline late 1990s (1998-2001) & $-0.86 * *$ & -0.05 & $3.28 * * *$ & $0.95^{* *}$ \\
\hline vs early 1990s (1989-1993) & $(0.43)$ & $(0.50)$ & $(0.93)$ & $(0.47)$ \\
\hline mid-1990s (1994-1997) & $-1.16 * *$ & -0.17 & $2.45^{* * *}$ & 0.48 \\
\hline vs early 1990s (1989-1993) & $(0.48)$ & $(0.54)$ & $(0.95)$ & $(0.51)$ \\
\hline \multicolumn{5}{|l|}{ External learning mechanisms } \\
\hline learning from knowledge spillovers vs & 0.60 & $1.96 * * *$ & $-1.17^{*}$ & 0.03 \\
\hline no learning & $(0.51)$ & $(0.72)$ & $(0.61)$ & $(0.48)$ \\
\hline learning from advances in S\&T and & $2.61 * * *$ & $2.20 * * *$ & 0.01 & -0.54 \\
\hline education vs no learning & $(0.56)$ & $(0.83)$ & $(0.66)$ & $(0.67)$ \\
\hline learning by interacting & 0.29 & 0.88 & $-2.28 * * *$ & 0.33 \\
\hline vs no learning & $(0.51)$ & $(0.71)$ & $(0.68)$ & $(0.45)$ \\
\hline \multicolumn{5}{|l|}{ Internal learning mechanisms } \\
\hline 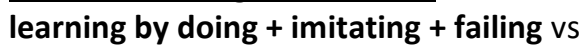 & 0.33 & $1.92 * * *$ & -0.20 & -0.03 \\
\hline no learning & $(0.49)$ & $(0.61)$ & $(0.69)$ & $(0.44)$ \\
\hline learning by using + monitoring & 0.47 & 0.84 & 0.49 & 0.04 \\
\hline vs no learning & $(0.43)$ & $(0.62)$ & $(0.61)$ & $(0.45)$ \\
\hline learning by training +research & $1.81^{* *}$ & $2.70 * * *$ & $4.08 * * *$ & $3.00 * * *$ \\
\hline vs no learning & $(0.72)$ & $(0.84)$ & $(0.81)$ & $(0.70)$ \\
\hline \multicolumn{5}{|l|}{ Level of knowledge sharing within the firm } \\
\hline \multirow[t]{2}{*}{ within unit vs within firm } & $2.01 * * *$ & 0.49 & $-2.59 * * *$ & -0.48 \\
\hline & $(0.63)$ & $(0.65)$ & $(0.58)$ & $(0.53)$ \\
\hline inter-personal/inter-unit & $1.16^{*}$ & 0.92 & $-1.78 * * *$ & 0.59 \\
\hline vs within firm & $(0.65)$ & $(0.63)$ & $(0.55)$ & $(0.50)$ \\
\hline No of observations & 467 & Prob > Chi-Square & 0.000 & \\
\hline Log Likelihood & -354.774 & Psuedo $\mathrm{R}^{2}$ (McFadden) & 0.270 & \\
\hline LR Chi-Square & 395.685 & Correct Classification & $52.9 \%$ & \\
\hline Degrees of freedom & 40 & Reference outcome & No upgrading & \\
\hline Variable Selection Method used & $\begin{array}{c}\text { Stepwise (backward } \\
\text { elimination) }\end{array}$ & Variable removed & INDUSTRY & \\
\hline
\end{tabular}

Source: Own dataset, SPSS version 17.0 
Managerial upgrading. There is clear indication of Polish food-processing and clothing firms' increasing attention to managerial upgrading within the firm since mid-1990s onwards. There is significant increase in the negative coefficient of links that lead to learning-by-interacting and learning from knowledge spillovers to managerial upgrading compared to in Model 1. This can be explained by the statistically significant mediating effect (at $1 \%$ level) of learning-by-training and research: the links that create synergy for learning by training and research within the firm are almost 60 times more likely to contribute to managerial upgrading than the links that cannot create it. Sharing externally acquired knowledge within and between units is less likely to contribute to managerial upgrading than sharing such knowledge at all levels of the firm. This indicates that managerial upgrading is rooted in the activities that concern the entire firm and requires a more holistic approach within the firm.

Functional upgrading. Links that started in the late $1990 \mathrm{~s}$ are still (2.6 times) more likely to contribute to functional upgrading than those started in the early 1990s. However, when the mediators are controlled for, the effect of external learning mechanisms on functional upgrading disappears altogether. This indicates 'perfect mediation' by learning by training and research between learning-byinteracting and functional upgrading (almost 20 times more likely to contribute to functional upgrading) (Baron and Kenny 1986). However, KNOWSHARE is not statistically significant at all.

\section{Discussion}

The results of Model 1 show that external learning through networks over the transition years paved the way for emergence of managerial and functional upgrading within the Polish LMT firms while the importance of process upgrading (in the form of modernisation of machinery and equipment) subsided. These results indicate that the emerging market LMT firms' preference in the early transition years for using technology transfer to expand production capacity had been replaced by preference for building organisational capabilities in the late 1990s. Product upgrading is a continuing priority for firms all the time.

The results of Model 2 identify the mediating effect of internal learning mechanisms on the relationship between external learning mechanisms and firm-level upgrading types; accounting for why and how external learning creates upgrading within the firm. The major mediator appears to be 'learning by training and research', as the most significant contributor to all types of firm-level upgrading, making it a potent condition for external learning mechanisms to affect all types of upgrading (the parameters are all positive and highly significant at $1 \%$ level), except process upgrading (significant at $5 \%$ level).

When the timeline is examined, there is an increase in the contribution of the links started in late1990s/early 2000s to the likelihood of managerial and functional upgrading. Combined with the mediating effect of learning by training and research, this result indicates improvement in the absorptive capacity of the firms for organisational upgrading that led to an increasing awareness within the firms of the importance of complementary role of internal factors to external. The statistical evidence on the Polish food industry supports these findings as firms increased their staff training connected with innovation activities from $0.9 \%$ of the expenditures on innovation activities in 2000 to 2.6\% in 2007 (Central Statistical Office of Poland - GUS 2002, 2009).

\subsection{Process upgrading as the foundation of firm-level upgrading in the early transition years}

Technological needs of the Polish food-processing and clothing firms centred primarily on upgrading their production process technologies in the early 1990s, considering that the last technological improvements in most firms were conducted in the 1970s industrialisation period. This means the modernisation of production facilities, machinery and equipment and the introduction of technological advances to increase their productivity. 
In the early 1990s, Polish food-processing and clothing firms upgraded their process technology through having recourse to their established domestic relations with universities and public research institutes, who provided scientific expertise and advice. These relations were gradually replaced with relations with foreign technology suppliers, and eventually disappeared (cf. Radosevic 1999b). The technology acquisition links were not pursued either. Mostly down to financial reasons, instead of trying to frequently renew their core technologies with the purchase of newest available machinery and equipment, firms prioritised informal relationships to learn about technological developments in particular technologies and their application to specific production processes as well as research collaboration with reputable universities or research institutes.

The indirect effect of global buyers (in GVCs) in these firms' process upgrading lies in the investment inducement (Ernst 1997), sometimes as a direct requirement from the global buyer before starting a business with the Polish firm and sometimes as a result of competitive pressures with domestic and foreign rivals. For instance, the stronger market leaders among the clothing firms had their own CAD systems since the early 1990s and introduced automatic cutting machines in the mid-1990s (our interviews).

While we don't observe mediating effect of learning by training and research on process upgrading, we observe the spiral of knowledge internalisation within the firm only in process upgrading (i.e. knowledge frequently shared more informally within the unit, and between people and among units). Although this is an indication for low levels of absorptive capacity in the firm, it is hard to say whether effective use of the acquired technology was more dominant than its effective assimilation for catching-up (cf. von Tunzelmann 1995, Freeman and Soete 1997).

Nevertheless, focusing first on the process upgrading is desirable in the context of emerging market firms, as it sets the foundation for gradual implementation of other upgrading types.

\subsection{Product upgrading based on reverse engineering}

The contribution of learning from advances in S\&T to product upgrading is not very surprising. It seems natural in LMT industries that the acquisition of new process technologies generally precedes the development of new products, as technology and product dimensions are strictly interrelated (Nicholas 1996, von Tunzelmann and Acha 2005). In the early 1990s, Polish LMT firms initiated arm's length ties and knowledge networks, actively sourcing for new knowledge, and what they learned from these new advances not only contributed to their process upgrading but also to their product upgrading.

However, food-processing firms are one-half as likely to upgrade their products through their external relationships as clothing firms. For food-processing firms, knowledge networks as a source of new product development are not as effective as sources for product development used by the clothing firms. The latter are interacting with global buyers within GVCs/GPNs and are linked to international product movements. Yet, learning by interacting is not likely to contribute to product upgrading, unless learning by doing, imitating and failing and learning by training and research act as potent conditions for this effect to occur. This result confirms the link between learning by doing and learning by interacting (GVCS/GPNs) for product upgrading.

Moreover, knowledge spillovers are readily available through GVCs/GPNs, leading to reverse engineering (observation, imitation and adaptation) on new/similar product development (Mowery and Oxley 1995), and through product design specification, involvement in prototype development, informal sharing of technical and marketing information on customer's products (Ernst 1997). Polish foodprocessing and clothing firms mimicked foreign firms in product development, differentiation and product marketing strategies. In order to do so, they also intensively trained their staff through 
collaboration with university departments and specialised consulting firms, which provided the type of education and training needed by these firms at the time. The internalisation of technical knowledge by imitation led to higher opportunities for competence-building and therefore product upgrading.

\subsection{Managerial upgrading as a pre-requisite for functional upgrading}

Strikingly, the estimation results for Model 1 showed that learning by interacting impedes managerial upgrading within the firm. Due to strong association between learning by interacting and production \& distribution networks, we can infer that GVCs/GPNs per se impedes managerial upgrading. This finding for the transition period is consistent with the literature that global buyers, global marketers (e.g. hypermarkets) do not want their suppliers to encroach on their core competences, and therefore they share information and knowledge carefully and up to a limit where they can control the upgrading of their suppliers (Schmitz 2006, Bazan and Navas-Aleman 2004, Tokatli and Eldener 2004, Schmitz and Knorringa 2000). So, GVCs/GPNs do not constitute means for managerial upgrading, and there is no significant effect of other learning mechanisms on managerial upgrading. If interacting with global buyers in GVCs/GPNs do not contribute, then what does contribute to eliminating the deficiencies of Polish LMT firms in managerial capabilities? This question is answered by the results of Model 2 for managerial upgrading in relation to time period.

The Polish LMT firms achieved process upgrading through links in the early transition years, managerial upgrading through links since the mid-1990s, and functional upgrading since the late 1990s / early 2000s. These results are in line with the expected and realised outcome of privatisation and enterprise restructuring in the Polish manufacturing industry, which started in the mid-1990s, and represented a recovery for LMT industries. In addition, inflow of FDI gained momentum in the mid-1990s, particularly in the food-processing industry. Managerial upgrading starts earlier than functional upgrading within the firm.

Becoming a focus of the firms as late as early 2000 s, relative to other upgrading types, functional upgrading emerges as a new type of upgrading within the Polish LMT firms, providing evidence that functional upgrading is not an automatic and natural result of being inserted in GVCs/GPNs, as the upgrading literature puts forward. This result proves that functional upgrading requires accumulation of knowledge and capabilities specific for it, one of which is managerial capabilities (Penrose 1959); hence, as the results of the effects of time period on types of upgrading also show, the managerial upgrading preceding functional upgrading is no coincidence. Based on these results, managerial upgrading (a forgotten type of upgrading or an upgrading type that is taken as granted) appears to be a pre-requisite for functional upgrading.

As opposed to the findings of Gentile-Ludecke and Giroud (2009) in Polish automotive industry, in the food-processing and clothing industries, we found that learning by interacting and learning from knowledge spillovers impede managerial upgrading within the firm. According to our results, contrary to the expectations, the contribution of these learning effects from (in)voluntary knowledge spillovers from global buyers in GVCs/GPNs in managerial practices (Ernst 1997, Saliola and Zanfei 2009) are not observed with regard to managerial upgrading in Polish LMT firms. This may be related to the industries studied being low- to medium-tech industries in particular, in which case FDI spillovers do not contribute to upgrading as much as in high-tech industries, confirming the findings of Weresa (2004).

Managerial upgrading requires strong internal incentives and effort, almost always by the management itself; hence, learning in networks impedes this form of upgrading more than it contributes. The less likelihood of managerial upgrading through inter-organisational learning seems to be compensated with internal knowledge sharing mechanisms at all levels of the firm. This makes sense when the learning by training and research is also a significant and positive contributing factor to managerial upgrading within the firm. 


\subsection{Functional upgrading via GVCs and complementary internal learning by training and research}

Whether insertion into GVCs provides a route to functional upgrading is a disputable issue in the upgrading literature (Schmitz 2006, Tokatli 2013, Blazek 2015). Most of the case evidences suggest that GVCs/GPNs hinder functional upgrading (Navas-Aleman 2006, 2011, Bazan and Aleman 2004, Bair and Gereffi 2001, Kaplinsky et al. 2002, Schmitz and Knorringa 2000, Humphrey and Schmitz 2000, Gibbon 2000). Would this controversy be due to focusing only on moving into new functions in the 'chain'? There are functions that are not related to chain activities, but firms upgrade into.

Schmitz (2006) also argues that the chain approach cannot explain the underlying reasons why firms sometimes are able to functionally upgrade and sometimes not. Precisely, there are other organisational forms that may lead to functional upgrading such as knowledge networks as this paper examines. Can the controversy be arising from operating in multiple value chains and/or being involved in other kinds of links than chains?

Some of the earlier findings in the upgrading literature suggest that being inserted in GVCs/GPNs and learning by interacting with global buyers are not sufficient for functional upgrading, and arm's length relations of local firms may contribute but resource requirements are so high that there is lack of investment. The case studies posit that local firms that operate in market-based chains in the (large) domestic or regional markets ${ }^{12}$ are able to achieve functional upgrading because they experience neither support for nor blockage to upgrading (Hsing 1999, Bazan and Navas-Aleman 2004, Schmitz 2006, Navas-Aleman 2011). In our analysis, we found that rather than supporting functional upgrading, arm's length ties are associated with technology transfer purposes which lead to process upgrading (and, as a result of process development, product upgrading) when compared to production and distribution networks.

Moreover, these case studies show that working with small-scale global buyers facilitates functional upgrading; "[h]owever, local producers do not necessarily make the required investment for functional upgrading" (Schmitz 2006: 560). Recent work in the upgrading literature argues that functional upgrading is all about acquiring new skills and capabilities that are new to the firm through investments for resources (Navas-Aleman 2011). The literature focuses mostly on the financial side of the internal efforts that are undertaken by the firm for functional upgrading. It is true that they are costly investments such as marketing in foreign markets which requires strong financial standing and substantial risk-taking; particularly for small supplier firms. Yet, for large firms which could afford such investments in equipment, organisational arrangements and people, the intriguing question is what defers their functional upgrading.

Our findings show that the positive and significant effect of 'learning by interacting' and 'learning from knowledge spillovers' on functional upgrading (in Model 1) provides strong evidence for learning facilitation effect of GVCs/GPNs (at least up to ODM level ${ }^{13}$ ) (Hobday 1995, 2003, Ernst 1997, Yoruk 2004, Kishimoto 2004, Pickles et al. 2006, Plank and Staritz 2015). However, this effect is only possible with the strong and effective presence of 'learning by training and research within the firm' (i.e. the perfect mediation in Model 2). In other words, our findings suggest that it is not that supplier firms do not learn about new skills such as branding, design and marketing through GVCs/GPNs, but there are issues concerning how effective this external knowledge is internalised in each and every firm. Hence,

\footnotetext{
12 In the terminology of this research, this is similar to Original Brand Manufacturing (OBM) in the domestic markets and Original Design Manufacturing (ODM) in export markets, e.g., with retailers who buy the design of the Polish supplier and sell it under its own brandname (see Schmitz 2006: 559 for the definition of market-based chains).

${ }^{13}$ Based on Hobday's (1995) learning trajectory of OEM-ODM-OBM that shows the importance of incremental and minor improvements for catching up or keeping up with developed country firms.
} 
being integrated into GVCs/GPNs may create stimulus for functional upgrading, but the internal dynamics of the firm play the key role in successful functional upgrading.

After all, functional upgrading requires being an active learner, being aware of the need to combine externally acquired knowledge with internal resources and capabilities, and achieving high levels of absorptive capacity within the firm - all related to the firm capabilities. A striking fieldwork observation from Polish clothing firms sheds light on why barriers are not finance-related, but capability-related. As this paper examines large firms with better financial standing compared to SMEs, among the firms we interviewed, three of them made investments to become network organisers of domestic production networks for their own brands ${ }^{14}$, but still failed. All had strong brand-names in their market, so they heavily invested in marketing and the network of domestic suppliers but they either could not cultivate in-house design capabilities to support brand or could not manage a big network of suppliers. Firms that tried to establish such functional upgrading based on externally hired capabilities have failed. Passive internal learning mechanisms such as learning by doing or learning by using do not contribute to functional upgrading within the firm.

Polish clothing firms that achieved successful functional upgrading to OBM in the Polish market and ODM in the export market built their success on forming core competences in various business functions through internalisation of knowledge and technology they acquired while in GVCs/GPNs and in other types of links over years. This is a result of several factors (Yoruk 2002, 2013). First, GVCs/GPNs have significant bearing on the Polish LMT firms' acquisition of new functions such as increasing process and product quality; and of new capabilities in the areas of raw material procurement, design and marketing. Second, over the transition years, the increasing competitive pressure from the suppliers in low-cost countries made Polish LMT firms react to the requirements of their partners for greater flexibility, quick response and service in addition to become the high-quality product supplier in the GVCs/GPNs, which in turn improved their overall organisational capabilities. Needless to say this required acquiring new capabilities and using organisational routines to pursue new opportunities in the market, though not necessarily only through GVCs/GPNs. Hence, third, these firms were alert and perceptive towards where the competitive edge of the industry hinges on today: on design skills, choice and use of new fabrics, meeting quality standards, development of marketing and distribution systems and efficient organisation of production stages/lines in addition to achieving competitiveness in hardware by investing in new machinery, new production lines, and computer systems - all of which are the requirements of growth and/or management of knowledge within the firm (Penrose, 1995) and necessary for leverage in the foreign markets.

The large Polish LMT firms we interviewed were operating in multiple GVCs (i.e. ODM for retailers / supermarkets in the Polish and export markets while working as OEM for the global buyers), were wellknown and reputable brand manufacturers of the communist era and have never abandoned their national market. ${ }^{15}$ So, while they viewed being inserted into GVCs as OEMs as 'downgrading', (particularly for food-processing firms which participated GVCs/ GPNs after becoming OBMs in their domestic and export markets), the truth is their design and product development capabilities were close to none when the communist system collapsed.

Through GVCs, they quickly realised where the market niches were in their specialisation and what they needed to do to improve their presence in the domestic market. GVCs, in other words, proved to be short-cut to information about the fashion markets, quality supply markets, and design patterns (learning facilitation effect of GPNs/GVCs, Ernst 1997). They first understood the importance of new

\footnotetext{
${ }^{14}$ Being a network organiser in the domestic market is an indication of upgrading in many functions these firms did not previously have the capability of.

${ }^{15}$ While the share of this function in total production decreased with OEM being inserted in, it was more profitable compared to $O E M$ and the firms were aspiring to increase its share gradually (based on our interviews).
} 
designs in every season for product differentiation moving beyond the standardised clothing of the socialist era (even in men's suits, a clothing category where differentiation was particularly undervalued). Then they realised that the quickest way to improve their presence in the domestic market is to imitate the designs of global buyers. Quality improvements through use of foreign fabric suppliers were introduced (due to the low credibility of Polish suppliers as a result of the collapse of Polish textile industry). At the same time, global buyers brought the information where the best quality foreign suppliers were and sometimes established a bargain price, of which Polish clothing firms made use to supply their own products while making purchase for the production of the global buyer. Finally they realised the importance of having their own designers - initially external ones, later followed by development of their own in-house design capabilities - all by the help of knowledge acquired/exposed in GVCs (knowledge spillover effects, , Ernst 1997). Moreover, like many emerging market firms, Polish clothing firms supported their functional upgrading through their earnings from the OEM production (whose share in production was always more than the share for their own production lines) (Pickles et al. 2006); it was a safeguard until they re-established their brands in the domestic market. In other words, for large Polish clothing firms which aspired to become like the global buyers, GVCs served as a source of finance for first survival and then for the investments in resources needed for functional upgrading (investment inducement, Ernst 1997).

Having said that, as the literature argues, the downside of the GVCS/GPNs is in the fact that global buyers establish barriers to prevent their suppliers from encroaching on their core competences (Tokatli and Eldener 2004, Schmitz 2006, Tokatli 2013). So, how can the marketing and distribution capability be acquired through insertion into GVCs or just by selling products to small trading companies? As downstream activities, marketing and distribution have never been a part of the domain of suppliers in GVCs. They lie within the core competences of the global buyers which they did not need to share with their suppliers. Although their successful marketing, sales and distribution operations became exemplars to those suppliers who wanted to become like the global buyers in their domestic markets, to start with, they never had access to such tacit knowledge. This is where Polish LMT firms turn to other type of links in order to learn these new functions (i.e. through learning from knowledge spillovers); these (based on our interviews) included licensing and franchising of global brands for marketing and distribution in the Polish market, an alliance with a complementary firm to market products together at home and abroad, or working with a (foreign) consulting firm in order to initiate marketing. As a result, over the transition years, however, they functionally upgraded by becoming an ODM for the export markets and developed confidence quicker than expected to rejuvenate their reputation as OBMs in the Polish market. Subsequently, some became network organisers of domestic production networks within the Polish market (i.e. in the way GVC/GPNs were governed), while others became OEMs and ODMs for them in addition to GVCs. In this sense, the route of functional upgrading of Polish clothing firms that operate in multiple chains provide a different and complex case compared to existing cases in the literature (Yoruk 2004).

As a result, functional upgrading is partly related to the insertion in GVCs/GPNs and partly a consequence of increasing role of global buyers without manufacturing expertise (such as retailers) in GVCs/GPNs, but most importantly it is an outcome of path-dependency which leads to development of learning mechanisms within the firm through training and research activities. ${ }^{16}$

\section{Conclusion}

\subsection{Contributions}

16 Yoruk (2004) explains the background for this achievement. 
This paper explored the sources of firm-level upgrading that stemmed from learning in networks. It developed a dynamic model of firm-level upgrading by distinguishing varieties of networking activities of the firm within different systems and by unpacking learning mechanisms external to the firm with particular interest in learning that takes place in a relationship. Predictive models of types of firm-level upgrading for the sample of relationships established by Polish food-processing and clothing firms were used for this exploration. The models were built upon learning in networks that is defined as a twostage process of inter- and intra-organisational knowledge transfer and learning consecutively.

The analysis in this paper answered how learning in networks contribute to firm-level upgrading. It examined in detail the impact of knowledge transfer/acquisition during networks on firm-level upgrading by means of external learning mechanisms. But most importantly, it found the mediating effect of knowledge internalisation variables and threw a new light on the causal relationship between external learning mechanisms and types of firm-level upgrading.

The analysis in this paper generated a number of novel findings. The results for product upgrading largely confirm the previous findings in the literature. However, process upgrading is a function of learning from advances in science and technology through knowledge networks. Strikingly, learning-byinteracting in production networks impedes not functional, but managerial, upgrading, a previously unexplored upgrading type, which is shown to be a pre-requisite for functional upgrading. While learning-by-training and research within the firm is a potent condition for external learning mechanisms to contribute to all upgrading types, for successful functional upgrading, it is a must. It appears that the only way for the emerging market country firms not to have lock-in effects of GVCs/GPNs, and therefore not to become an integral part of an 'assembly economy', is to develop managerial capabilities for successful technological upgrading.

Overall, there are two key findings. These are the necessity and importance of the adopted integrative approach to learning in upgrading research and the complementarity between organisational (managerial and functional) and technology (product and process) upgrading. Looking at the pattern of upgrading in our analysis, initial technology upgrading of early 1990s targets closing the gap in physical capital. Mid-1990s witnesses the efforts to close the gap in human capital, and so managerial upgrading precedes functional upgrading. The attainment of organisational upgrading at a reasonable level paves the way for a successful technology upgrading, where innovative capabilities gradually emerge (e.g. in the form of design).

\subsection{Limitations and further research}

While this research design and analysis have provided robust findings, hence better understanding of the role of networks in firm-level upgrading, this research is not without limitations. This research focuses on sixteen firms in two sectors in one country, which suggests some caution in generalization. Also the network data of this research was constructed as dyadic relationships between the chosen core firm (i.e. Polish firm) and a specific partner. In the time period investigated these dyadic relationships did not demonstrate a multitude of interconnectedness, such as knowing one partner leading to creation of other dyadic relations with a common third partner (called 'transitivity'). Majority of them represented uni-directional knowledge transfer, meaning there was little 'reciprocity' in these dyadic relations (Snijders et al., 2010). In terms of network dynamics, these characteristics of the data indicated a markedly low mutual dependence among multiple dyadic relations and allowed us to make a decisive choice of using MLR analysis to predict the probability of different firm-level upgrading types in the early transition years by identifying their distinguishing and/or common characteristics in different industries. At the same time, we can deduce that network structures in early transition years were simpler than today's more sophisticated network structures. So, if a follow-up research on these firms for a longitudinal study is conducted (e.g. to compare the impact of today's networks' on firm- 
level upgrading with that of transition years' networks), then recent methodologies that investigate network dynamics such as stochastic actor-oriented models (SAOM) can be utilised.

Some of the findings also open up avenues for further research. For instance, findings suggest that complying with global quality standards through learning from advances in S\&T has no contribution to functional upgrading of the emerging markets firms. This is consistent with the work of upgrading researchers (Quadros, 2004; Nadvi 2004). Why this is so constitutes a question for further research. Moreover, it is surprising to find that sharing externally acquired knowledge at different levels within the firm has no significant contribution to product and functional upgrading types. A further research question would investigate whether this would be because of their link to process and managerial upgrading respectively.

\section{Acknowledgements}

I gratefully acknowledge a generous financial support of the fieldwork for this research by the project 'The Emerging Industrial Architecture of the Wider Europe; the Coevolution of Industrial and Political Structures', funded by the ESRC programme 'One Europe or Several?' at University College London, when I was working as a research fellow.

\section{References}

Almeida, P., G. Dokko, and L. Rosenkopf (2003) "Startup size and the mechanisms of external learning: increasing opportunity and decreasing ability?", Research Policy, 32: 301-315.

Anderson, J. C. and H. Hakansson, J. Johanson, 1994, "Dyadic business relationships within a business network context", Journal of Marketing, 58 (4): 1-15.

Arino, A. and J. de la Torre (1998) "Learning from Failure: Towards an Evolutionary Model of Cooperative Ventures", Organization Science, 9(3): 306-325.

Arrow, K.J. (1962) "The Economic Implications of Learning by Doing", Review of Economic Studies, 29: 155-173.

Audretsch, D., E. Lehmann and S. Warning (2004) "University Spillovers: Does the Kind of Science Matter?", Industry \& Innovation, 11(3):193-206.

Bair, J. (2005) "Global Capitalism and Commodity Chains: Looking Back, Going Forward", Competition \& Change 9(2): 153-180.

Bair, J. and G. Gereffi (2001) "Local clusters in global chains: The causes and consequences of export dynamism in Torreon's Blue Jeans Industry", World Development, 29(11): 1885-1903.

Barner-Rasmussen, W., and I. Bjorkman (2005) "Surmounting interunit barriers: Factors associated with inter-unit communication intensity in the multinational corporation", International Studies of Management \& Organization, 35(1): 28-46.

Baron, R.M. and D.A. Kenney (1986) "The moderator-mediator variable distinction in social psychological research: Conceptual, strategic, and statistical considerations", Journal of Personality and Social Psychology, 51(6): 1173-1182.

Bazan,L. and Navas-Aleman (2004) "The underground revolution in the Sinos Valley: A comparison of upgrading in global and national value chains", in H. Schmitz (ed.) Local Enterprises in the Global Economy. Issues of Governance and Upgrading, Edward Elgar: Cheltenham, UK, pp.110-139.

Bell, M. (2006) "Time and technological learning in industrialising countries: how long does it take? How fast is it moving (if at all)?", International Journal of Technology Management, 36 (1-3):25-39.

Bell, M. and K. Pavitt (1993) "Technological Accumulation and Industrial Growth: Contrasts between developed and developing countries", Industrial and Corporate Change, 2(2): 157-210.

Bell, M. and M. Albu (1999) "Knowledge Systems and Technological Dynamism in Industrial Clusters in Developing Countries", World Development, 27(9):1715-1734. 
Blazek, J. (2016) "Towards a typology of repositioning strategies of GVC/GPN suppliers: the case of functional upgrading and downgrading", Journal of Economic Geography, 16: 849-869.

Borooah, V.K. (2002) Logit and Probit: Ordered and Multinomial Models, Sage University paper.

Borrus, M., D. Ernst and S. Haggard (eds.) (2000) International Production Networks in Asia. Rivalry or Riches?, Routledge, London.

Brass, D. J., J. Galaskiewicz, H. R. Greve, And W. Tsai (2004) "Taking Stock of Networks and Organizations: A Multilevel Perspective", Academy of Management Journal, 47(6): 795-817.

Brewer, B. D. (2011) "Global commodity chains \& world income inequalities: the missing link of inequality and the 'upgrading' paradox", Journal of World-Systems Research, 17: 308-327.

Brown, J.S. and P. Duguid (1991) "Organisational Learning and Communities-of-Practice: Toward a Unified View of Working, Learning and Innovation", Organisation Science, 2(1): 40-57.

Caves, R.E. (1999) "Spillovers from multinational in developing countries: The mechanisms at work", Working Paper No. 247, William Davidson Institute Conference on "The Impact of Foreign Investment on Emerging Markets", School of Business Administration, University of Michigan, Ann Arbor.

Central Statistical Office of Poland (2009) Science and Technology in Poland.

Central Statistical Office of Poland (2002) Innovation Activities in Industrial Enterprises in Poland 19982000, Warsaw.

Chandler, A.D. Jr (1996) "Corporate Strategy, Structure and Control Methods in the United States during the Twentieth century" in G. Dosi and F. Malerba (eds.), Organization and Strategy in the Evolution of the Enterprise, London, MacMillan, pp.223-245.

Choksy, U.S., N. Sinkovics and R.R. Sinkovics (2017) "Exploring the relationship between upgrading and capturing profits from GVC participation for disadvantaged suppliers in developing countries", Canadian Journal of Administrative Sciences, 34(4):356-386

Coe, N. M. and H. W-C. Yeung (2015) Global production networks Theorising Economic Development in an Interconnected World, Oxford: Oxford University Press.

Coe, N. M., Hess, M., Yeung, H. W-C., Dicken, P., Henderson, J. (2004) “Globalizing regional development: a global production networks perspective", Transactions of the Institute of British Geographers, 29: 468-484.

Coe, N.M., P. Dicken and M. Hess (2008) "Global production networks: realizing the potential”, Journal of Economic Geography 8: 271-295.

Cohen, W. M. and D.A. Levinthal (1990) "Absorptive capacity: A New Perspective on Learning and Innovation", Administrative Science Quarterly, 35:128-152.

Contractor, F. J. (1998) "Technology Acquisition Policies in Emerging Markets", in F.J. Contractor (ed.), Economic Transformation in Emerging Countries. The Role of Investment, Trade and Finance. Series in International Business and Economics, Elsevier, Oxford.

Coombs, R. and J.S. Metcalfe (2000) “Organizing for Innovation: Coordinating Distributed Innovation Capabilities", in N. Foss and V. Mahnke (eds.), Competence, Governance and Entrepreneurship. Advances in Economic Strategy Research, Oxford, Oxford University Press, pp. 209-231.

Creswell, J., and V. Plano Clark (2007) Designing and conducting mixed methods research. Thousand Oaks, CA: Sage.

Creswell, J.W. (2003) "Research Design: Qualitative, Quantitative, and mixed methods approaches", second edition, ucalgary.ca/paed/files/paed/2003_creswell_a-framework-for-design.pdf

Dahlman, C. J. and F.V. Fonseca, (1987)" From Technological Dependence to Technological Development: The Case of the USIMINAS Steel Plant in Brazil", in J. Katz, (ed.) (1987) Technology Generation in Latin American Manufacturing Industries, New York: St Martin's Press, pp.154-181.

Daim, T.U. and D.F. Kocaoglu (2008) "Exploring technology acquisition in Oregon, Turkey and in the US electronics manufacturing companies", Journal of High Technology Management Research, 19:45-58.

Dicken, P. (1992) Global Shift: The Internationalisation of Economic Activity, London: Paul Chapman Publishing.

Dosi, G. (1988) "Sources, Procedures, and Microeconomic Effects of Innovation", Journal of Economic 
Literature, 24: 1120-1171.

Dutrenit, G. (2000) Learning and Knowledge Management in the Firm, Edward Elgar, Cheltenham.

Easterby-Smith, M., M. A. Lyles and E.W. K. Tsang (2008) "Inter-Organizational Knowledge Transfer: Current Themes and Future Prospects", Journal of Management Studies 45:4, 677-690.

Edquist, C., L. Hommen and M. McKelvey (2001) Innovation and Employment, Process versus Product Innovations, Cheltenham: Edward Elgar.

Ernst, D. (2009) "A New Geography of Knowledge in the Electronics Industry: Asia's Role in Global Innovation Networks", East-West Center Policy Studies, No. 54.

Ernst, D., 2008. Innovation offshoring and Asia's electronics industry - the new dynamics of global networks, International Journal of Technological Learning, Innovation and Development, 1(4): 551576.

Ernst, D., (2001) “Global Production networks and Industrial Upgrading - A Knowledge Centred Approach", East-West Center Working Papers, Economics Series, No. 25.

Ernst, D., (1998) "Catching-Up, Crisis and Industrial Upgrading. Evolutionary Aspects of Technological Learning in Korea`s Electronics Industry ", Asia Pacific Journal of Management, Volume 15 (2): 247283.

Ernst, D., (1997) "From Partial to Systemic Globalization: International Production Networks in the Electronics Industry", BRIE Working Paper 98.

Ernst, D., T. Ganiatsos and L. Mytelka, (eds.) 1998. Technological Capabilities and Export Success Lessons from East Asia, Routledge Press, London.

Ernst, D. and L. Kim, 2002. Global production networks, knowledge diffusion, and local capability formation, Research Policy, 31 (2002) 1417-1429.

Figueiredo, P.N.,2010. Uncovering the learning mechanisms underlying pathways of disruptive innovation capability accumulation in latecomer natural resource-processing firms: Evidence from Brazil, paper presented in Druid Summer Conference. www2.druid.dk/conferences/viewpaper.php?id=502061\&amp;cf=43</cite>

Freeman, C. (1994) "Innovation and Growth", in M. Dodgson and R. Rothwell (eds.) The Handbook of Industrial Innovation, Aldershot, Edward Elgar, pp.78-93.

Freeman, C. and J. Hagedoorn (1994) "Catching Up or Falling Behind: Patterns of International Interfirm Technology Partnering", World Development, 22(5): 771-780.

Freeman, C. and L. Soete (1997) The Economics of Industrial Innovation, third edition, Pinter, London.

$\mathrm{Fu}, \mathrm{X}$., C. Pietrobelli, L. Soete, 2011. The Role of Foreign Technology and Indigenous Innovation in the Emerging Economies: Technological Change and Catching-up, World Development, 39 (7): 12041212.

Gentile-Ludecke, S. and A. Giroud (2009) "Does the East Learn from the West? How Polish Automotive Suppliers Learn from Western MNEs", Journal of East-West Business, 15(3): 271- 294.

Gereffi, G., (1994) "The organisation of buyer-driven commodity chains: how US retailers shape overseas production networks", in G. Gereffi and M. Korzeniewicz (eds.) Commodity chains and global capitalism. Westport: Greewood Press, 95-122.

Gereffi, G. (1999) "International Trade and Industrial Upgrading in the Apparel Commodity Chain, Journal of International Economics, 48: 37-70.

Gereffi, G., J. Humphrey and T. Sturgeon, 2005. The Governance of Global Value Chains, Review of International Political Economy, 12(1): 78-104.

Gereffi, G. and J. Lee (2012) "Why the world suddenly cares about global supply chains", Journal of Supply Chain Management, 48: 24-32.

Geroski, P. and M. Mazzucato (2002) "Learning and the sources of corporate growth", Industrial and Corporate Change, 11(4):623-244.

Gibbon, P. (2000) "Back to the Basics through Delocalisation: The Mauritian Garment Industry at the End of the Twentieth Century", CDR Working Paper 00-7, Copenhagen: Centre for Development Research.

Ghoshal, S., Korine, H., \& Szulanski, G. (1994) "Inter-unit communication in multinational corporations", 
Management Science, 40(1): 96-110.

Goh,S. and G. Richards (1997) "Benchmarking the Learning Capability of Organizations", European Management Journal, 15(5):575-583.

Greene, J. C., 2007. Mixing methods in social inquiry. San Francisco: Jossey-Bass.

Greene, W.H. (2008) Econometric analysis, Upper Saddle River, New Jersey, $6^{\text {th }}$ edition.

Gunther, J., 2005. Technology Spillovers from Foreign Investors in Transition Economies - Are the effects still expected?, Economic and Business Review for Central and South - Eastern Europe; 7(1): 5-24.

Hakansson, H. (1989) Corporate Technological Behaviour. Cooperation and Networks, London: Routledge.

Hakansson, H. (ed.) (1987) Industrial Technological Development. A Network Approach, London: Croom Helm.

Hakansson, H., V. Havila and A-C.Pedersen (1999) 'Learning in Networks', Industrial Marketing Management, 28: 443-452.

Hamel, G. (1991) "Competition for competence and inter-partner learning within international strategic alliances", Strategic Management Journal, 12: 83-103.

Hansen, M.T. (2002) "Knowledge networks: Explaining effective knowledge sharing in multiunit companies", Organization Science, 13(3): 232-248.

Hansen, M.T. (1999) "The Search-Transfer Problem: The role of weak ties in sharing knowledge across organization subunits", Administrative Science Quarterly, 44: 82-111.

Henderson, J., P. Dicken, M. Hess, N.M. Coe, and H. W-C Yeung (2002) 'Global production networks and the analysis of economic development', Review of International Political Economy, 9: 436-464.

Hess, M. (2008) "Governance, value chains and networks: an afterword", Economy and Society, 37 (3): 452-459.

Hess, M. and Wai-Chung Yeung H. (2006) 'Whither global production networks in economic geography?', Environment and Planning A, 38: 1193-1204.

Hite, J.M. and W. S. Hesterly (2001) 'The Evolution of Firm Networks: From Emergence of Early Growth of the Firm', Strategic Management Journal, 22: 275-286.

Hobday, M. (2003) "Innovation in Asian Industrialization: A Gerschenkronian Perspective", Oxford Development Studies, 31(3): 293-314.

Hobday, M., 1995. Innovation in East Asia: The Challenge to Japan, Edward Elgar, Cheltenham, UK.

Hosmer, D.W. and S. Lemeshow, 2000. Applied Logistic Regression, 2nd ed, Wiley-Interscience, Canada.

Hsing,Y.-T. (1999) "Trading companies in Taiwan's fashion shoe networks", Journal of International Economics, 48: 101-120.

Humphrey, J. and H. Schmitz (2008) "Inter-firm relationships in global value chains: trends in chain governance and their policy implications", International Journal of Technological Learning, Innovation and Development, 1(3):258-282.

Humphrey, J. and H. Schmitz, 2004. Governance in global value chains, in H. Schmitz (ed.) Local Enterprises in the Global Economy. Issues of Governance and Upgrading, Edward Elgar: Cheltenham, UK, 95-109.

Humphrey, J. and H. Schmitz, (2002) "How does insertion in global value chains affect upgrading industrial clusters?", Regional Studies, 36(9), 1017-1027.

Humphrey, J. and H. Schmitz, (2000) "Governance and Upgrading: Linking Industrial Cluster and Global Value Chain Research", IDS Working Paper 120, Brighton, IDS, University of Sussex.

Inkpen, A., 1998. Learning, Knowledge Acquisition and Strategic Alliances, European Management Journal, 16(2): 223-229.

Jensen, M.B., R. Johnson, E. Lorenz, B.A. Lundvall (2007) "Forms of knowledge andmodes of innovation", Research Policy 36: 680-693.

Johanson, J. and L-G. Mattson, 1987. Interorganizational Relations in Industrial Systems: A Network Approach Compared with the Transaction-Cost Approach, International Studies of Management and Organization, XVII (1):34-48. 
Kaplinsky, R., Morris, M., \& Readman, J. (2002) "The globalisation of product markets and immiserising growth: Lessons from the South African furniture industry", World Development, 30(7): 1159-1177.

Kaplinsky, R. and J. Readman (2000) "Globalisation and Upgrading: What Can (And Cannot) Be Learnt From International Trade Statistics In The Wood Furniture Sector?", Brighton: IDS, University of Sussex,www.ids.ac.uk/ids/global/valchn.html

Kaplinsky, R. and Hoffman, K. (1992) TNCs and the Transfer of New Management Practices to Developing Countries, Report prepared for UNCTNC, October, mimeo.

Kim, L. (1999a), Learning and Innovation in Economic Development, Cheltenham: Edward Elgar.

Kim, L. (1999b) "Building technological capability for industrialisation: Analytical frameworks and Korea's experience", Industrial and Corporate Change, 8(1): 111-136.

Kim, L., 1998. Crisis construction and Organizational Learning: Capability Building in Catching-up at Hyundai Motor, Organization Science, 9(4): 506-21.

Kim, L. (1997) Imitation to Innovation: The Dynamics of Korea's Technological Learning, Boston, Harvard Business School Press.

Kim, L., 1980. Stages of Development of Industrial Technology in a Developing Country: A Model, Research Policy, 9(3): 254-77.

Kishimoto, C. (2004) "Clustering and upgrading in the global value chains: The Taiwanese personal computer industry" in H. Schmitz (ed.) Local Enterprises in the Global Economy. Issues of Governance and Upgrading, Edward Elgar: Cheltenham, UK, pp.233-264.

Kogut, B. and U. Zander (1992) "Knowledge of the firm, combinative capabilities, and the replication of technology", Organization Science, 3: 383-397.

Lall, S. (2000) "The technological structure and performance of developing country manufactured exports, 1985-98", Oxford Development Studies, 28(3): 337-369.

Lane, P.J. and M. Lubatkin (1998) "Relative Absorptive Capacity and Interorganizational Learning", Strategic Management Journal, 19(5): 461-477.

Lee, K., 2013. Knowledge Regimes and Technological Catch Up, in Dutrenit, G. et al. (eds), Learning, Capability Building and Innovation for Development, Palgrave, McMillan, UK, pp.222-241.

Lee, K., K. Choo and M. Yoon, 2016. Comparing the productivity impacts of knowledge spillovers from network and arm's length industries: findings from business groups in Korea, Industrial and Corporate Change, 25(3): 407-427.

Lundvall, B.-Å (ed.) (1992) National Systems of Innovation - Towards a Theory of Innovation and Interactive Learning, London, Pinter Publishers.

Lyles, M. (1988) "Learning among joint venture sophisticated firms", in F.J.Contractor and P. Lorange (eds), Cooperative Strategies in International Business, Lexington Books, Lexington, MA, pp.301-316.

Madhavan, R., B. R. Koka, J. E. Prescott (1998) "Networks in transition: How industry events (re)shape interfirm relationship", Strategic Management Journal, 19(5): 439-459.

Malerba, F. (1992) "Learning by firms and incremental technical change", The Economic Journal, (102): 845-859.

McDermott, G.A. and R.A. Corredoira (2010) "Network composition, collaborative ties, and upgrading in emerging-market firms: Lessons from the Argentine autoparts sector", Journal of International Business Studies, 41: 308-329.

Meyer-Stamer, J. (2004) "Paradoxes and ironies of locational policy in the new global economy", in H. Schmitz (ed.) Local Enterprises in the Global Economy. Issues of Governance and Upgrading, Edward Elgar: Cheltenham, UK, pp.327-348.

Mowery, D. and J.E. Oxley (1995) "Inward Technology Transfer and Competitiveness: The Role of National Innovation Systems", Cambridge Journal of Economics, 19 (1):67-93.

Murray, F. (2002) "Innovation as co-evolution of scientific and technological networks: exploring tissue engineering", Research Policy, 31: 1389-1403.

Navas-Aleman, L. (2011) "The Impact of Operating in Multiple Value Chains for Upgrading: The Case of the Brazilian Furniture and Footwear Industries", World Development 38(4):1386-1397.

Navas-Aleman, L. (2006) “Opportunities and obstacles for industrial upgrading of Brazilian footwear and 
furniture firms: a comparison of global and national value chains", Unpublished PhD thesis, Brighton, IDS, University of Sussex.

Nelson, R. and S. G. Winter (1982) An evolutionary theory of economic change, Cambridge Massachusetts, Harvard University Press.

Nicholas, F. (1996) "Combined roles of process and product innovation in the food industries", in G.

Nicolini, D. and M.B. Meznar, 1995. The social construction of organizational learning: conceptual and practical issues in the field, Human Relations, 48 (7), 727-746.

Nonaka, I. (1994) "A Dynamic Theory of Organizational Knowledge", Organization Science, 5: 14-37.

OECD (2007) "Policy Mix for Innovation In Poland - Key Issues and Recommendations", Report prepared by OECD on the request made by Ministry for Science and Higher Education and Ministry of Economy, Warsaw, (accessed 29/04/2010) http://www.oecd.org/dataoecd/58/39/44960775.pdf.

Parilli, M.D., N. Khalid and H.W-C. Yeung (2013) "Local and Regional Development in Global Value Chains, Production Networks and Innovation Networks: A Comparative Review and the Challenges for Future Research", European Planning Studies, 21 (7): 967-988.

Pellegrin J. (2001) "'Learning by interacting' and catching up in Central and Eastern European countries: evidence from outward processing traffic", Journal of International Relations and Development, 4(3): 250- 273.

Penrose, E. (1959) The Theory of the Growth of the Firm, Oxford, Basil Blackwell.

Pickles, J. and A. Smith (2011) "Delocalization and Persistence in the European Clothing Industry: The Reconfiguration of Trade and Production Networks", Regional Studies, 45(2): 167-185.

Pickles, J., Smith, A., Buce `k, M., Roukova, P., and Begg, R. (2006) "Upgrading, changing competitive pressures, and diverse practices in the East and Central European apparel industry", Environment and Planning A, 38(12), 2305-2324.

Pietrobelli, C., and R. Rabellotti (2011) "Global Value Chains Meet Innovation Systems: Are There Learning Opportunities for Developing Countries?", World Development, 39(7): 1261-1269.

Pipkin, S. and A. Fuentes (2017) "Spurred to Upgrade: A Review of Triggers and Consequences of Industrial Upgrading in the Global Value Chain Literature", World Development Vol. 98, pp. 536-554.

Plank, L. and C. Staritz (2015) "Global competition, institutional context, and regional production networks: up- and downgrading experiences in Romania's apparel industry", Cambridge Journal of Regions, Economy and Society, 8: 421-438.

Ponte, S. and J. Ewert (2009) "Which way is 'up' in Upgrading? Trajectories of Change in the Value Chain for South African Wine", World Development, 37(10):1637-1650.

Powell, W.W. (1990) "Neither market nor hierarchy: Network forms of organization", in L. L. Cummings and B. M. Staw (eds.), Research in Organizational Behavior, 12: 295-336, Greenwich, CT: JAI Press.

Powell, W.W. and S. Grodal (2005) "Networks of Innovators", in J. Fagerberg, D.C. Mowery and R.R. Nelson (eds.), The Oxford Handbook of Innovation, Oxford, Oxford University Press, pp.56-85.

Powell, W.W., K. Koput and L. Smith-Doerr (1996). 'Interorganizational collaboration and the locus of innovation: Networks of learning in biotechnology', Administrative Science Quarterly, 41(1), pp. 116145.

Quadros, R. (2004) "Global Quality Standards and Technological Upgrading in the Brazilian AutoComponents Industry", in H.Schmitz, ed., Local Enterprises in the Global Economy: Issues of Governance and Upgrading, Edward Elgar Press, pp.265-296.

Radosevic, S. (1999a) International technology Transfer and Catch-up in Economic Development, Edward Elgar, Cheltenham.

Radosevic, S. (1999b) "Transformation of science and technology systems into systems of innovation in central and eastern Europe: the emerging patterns and determinants", Structural Change and Economic Dynamics, 10: 277-320.

Radosevic, S. and E. Yoruk (2018) Technology upgrading of middle income economies: A new approach and results", Technological Forecasting \& Social Change 129: 56-75.

Radosevic, S. and E. Yoruk (2016) "Why do we need a theory and metric of technological upgrading?" Asian Journal of Technology Innovation, 24(sup1): 8-32. 
Radosevic, S. and E. Yoruk (2015) "A new metrics of technology upgrading: the Central and East European countries in a comparative perspective", UCL CCSEE Working Paper, No. 2016/2, London: UCL School of Slavonic and East European Studies.

Rosenberg, N. (1982) "Learning by using", in N. Rosenberg, Inside the Black Box: Technology and Economics, Cambridge, Cambridge University Press, pp.120-141.

Sabel, C.F. (1994) "Learning by Monitoring: The Institutions of Economic Monitoring", in N. Smelser and R. Swedberg (eds.), Handbook of Economic Sociology, Princeton University Press-Sage, Princeton, pp. 137-165.

Saliola, F. and A. Zanfei (2009) "Multinational firms, global value chains and the organization of knowledge transfer", Research Policy, 38: 369-381.

Schein, E. (1985) Organizational Culture and Leadership, Jossey Bass, San Francisco, CA.

Schmitz, H. (2006) "Learning and Earning in Global Garment and Footwear Chains", The European Journal of Development Research, 18: 4, 546-571.

Schmitz, H. (ed.) (2004) Local Enterprises in the Global Economy. Issues of Governance and Upgrading, Edward Elgar: Cheltenham, UK.

Schmitz, H. and S. Strambach (2009) "The organisational decomposition of innovation and global distribution of innovative activities: insights and research agenda", International Journal of Technological Learning, Innovation and Development, 2(4): 231-249.

Schmitz, H. and P. Knorringa (2000) "Learning from Global Buyers", The Journal of Development Studies, 37(2): 177-205.

Snijders, T.A.B., G.G. van de Bunt and C.E.G. Steglich (2010) "Introduction to stochastic actorbased models for network dynamics", Social Networks 32: 44-60.

Sturgeon,T. (2008) 'Mapping integrative trade: conceptualizing and measuring global value chains, International Journal of Technological Learning, Innovation and Development, Vol. 1, No. 3:237-257.

Sturgeon,T. and G. Gereffi (2009) "Measuring success in the global economy: international trade, industrial upgrading, and business function outsourcing in global value chains, Transnational Corporations, 18(2): 1-36.

Szymanski, A., M. Gorton and L. Hubbard (2007) "A Comparative Analysis of Firm Performance in Postsocialist Economies: Evidence from the Polish Food Processing Industry", Post-Communist Economies, 19(4): 433-448.

Tabachnick, B.G. and L.S. Fidell (2007) Using Multivariate Statistics, Fifth Edition, Boston: Pearson Education Inc..

Tashakkori, A. and C. Teddlie, 2010. Putting the Human Back in "Human Research Methodology": The Researcher in Mixed Methods Research Journal of Mixed Methods Research, 4: 271.

Teddlie, C., \& Tashakkori, A., 2009. The foundations of mixed methods research: Integrating quantitative and qualitative techniques in the social and behavioral sciences. Thousand Oaks, CA: Sage.

Teece, D.J. (1996) "Firm organization, industrial structure, and technological innovation", Journal of Economic Behavior \& Organization, 31:193-224.

Teece, D., G. Pisano and A. Shuen (1997) "Dynamic Capabilities and strategic Management", Strategic Management Journal, 18(7): 509-533.

Tokatli, N. (2013) "Toward a better understanding of the apparel industry: a critique of the upgrading literature", Journal of Economic Geography, 13: 993-1011.

Tokatli, N. and Y.B. Eldener (2004) "Upgrading in the global clothing industry: the transformation of Boyner Holding", Competition \& Change, 8(2):173-193.

Uzzi, B. (1997) "Social Structure and Competition in Interfirm Networks: The Paradox of Embeddedness", Administrative Science Quarterly 42(1): 35-67.

Varga, A., 2000. Local academic knowledge transfers and the concentration of economic activity, Journal of Regional Science, 40: 289-309.

Veugelers, R. and B. Cassiman (1999) "Make and buy in innovation strategies: evidence from Belgian manufacturing firms", Research Policy, 28(1): 63-80.

Von Hippel, E. (1988) The Sources of Innovation, Oxford, Oxford University Press. 
Von Tunzelmann, G.N. and Q. Wang (2007) "Capabilities and production theory", Structural Change and Economic Dynamics, 18:192-211.

Von Tunzelmann, G.N. and V. Acha (2005) "Innovation in 'Low-Tech' Industries", in J. Fagerberg, D.C. Mowery and R.R. Nelson (eds.), The Oxford Handbook of Innovation, Oxford, Oxford University Press, pp.407-432.

Weresa, M.A. (2004) "Can foreign direct investment help Poland catch up with the EU?", Communist and Post-Communist Studies, 37 (2004) 413-427.

Wernerfelt, B. (1984) "A resource-based view of the firm", Strategic Management Journal, 5: 171-180.

Westphal, L.E., L.Kim and C.J. Dahlman (1984) “Reflections on Korea's Acquisition of Technological Capability", World Bank Development Research Department Discussion Paper.

Yoruk, D.E. (2013) Firm-level upgrading in low-and medium-technology industries in emerging markets: the role of learning in network, PhD Thesis. University of Sussex, SPRU, UK.

Yoruk, D.E. (2004) "Patterns of industrial upgrading in the clothing industry in Poland and Romania", in F. McGowan, S. Radosevic, N. von Tunzelmann (eds), The Emerging Industrial Structure of the Wider Europe, London: Routledge, pp. 95-110.

Yoruk, D.E. (2003) "Impact of inter-organisational networks on industrial upgrading at the firm level: Evidence from the Romanian food-processing industry", in New Europe College (ed.), NEC Yearbook, Bucharest.

Yoruk, D. E. (2002) "Effective Integration to Global Production Networks: Knowledge Acquisition and Assimilation. The Case of Braiconf SA in Romania". Working Paper Series No. 26, Centre for the Study of Economic and Social Change in Europe/School of Slavonic and East European Studies. London: University College London.

Yoruk, D. E. (2002) "Global Production Networks, Upgrading at the Firm Level and the Role of the Network Organiser: The Case of Vistula SA in Poland", Working Paper No. 28, Centre for the Study of Economic and Social Change in Europe/School of Slavonic and East European Studies. London: University College London.

Yoruk, E. (2011) "The influence of technological capabilities on the knowledge network component of innovation systems: evidence from advanced materials in Turkey", International Journal of Technological Learning, Innovation and Development, 4(4): 330-362.

Yoruk, E. and Yoruk, D.E. (2012) "Determinants of innovation in emerging market SMEs: Thirty-five years' evidence from advanced material in Turkey", In: Katzy, B., Holzmann, T., Sailer, K., Thoben, K.D. (Eds.), ICE 2012 Conference Proceedings, 'IEEE International Technology Management Conference'. Held 18-20 June 2012 in Munich, Germany. Strascheg Centre for Entrepreneurship, Munich, pp. 1-30.

Zysman, J., E. Doherty and A.Schwartz (1997) "Tales from the 'global' economy: Cross-national production networks and the reorganization of the European economy", Structural Change and Economic Dynamics, 8: (45-85).

\section{Appendices}

Table A.1 Network size and network density of the food-processing and clothing firms in the sample

\begin{tabular}{|l|l|l|l|l|l|}
\hline Food-processing firms & $\begin{array}{l}\text { Network } \\
\text { size }\end{array}$ & $\begin{array}{l}\text { Network } \\
\text { density }\end{array}$ & Clothing firms & $\begin{array}{l}\text { Network } \\
\text { size }\end{array}$ & $\begin{array}{l}\text { Network } \\
\text { density }\end{array}$ \\
\hline Meat processing & 44 & 0.23 & Men's and women's overcoats 1 & 47 & 0.17 \\
\hline Poultry & 36 & 0.18 & Men's suits 1 & 46 & 0.17 \\
\hline Fruit and vegetable preserves & 32 & 0.16 & Men's shirts, light dresses & 38 & 0.14 \\
\hline Dairy & 24 & 0.12 & Men's suits 2 & 36 & 0.13 \\
\hline Sugar & 21 & 0.11 & Women's light clothes & 34 & 0.13 \\
\hline Drinks and beverages & 15 & 0.08 & $\begin{array}{l}\text { Men and Women's light clothes, } \\
\text { knitted clothes }\end{array}$ & 26 & 0.10 \\
\hline Potato processing & 13 & 0.07 & Underwear/nightwear & 23 & 0.08 \\
\hline Confectionery & 10 & 0.05 & $\begin{array}{l}\text { Men's and women's overcoats, light } \\
\text { dresses 2 }\end{array}$ & 22 & 0.08 \\
\hline
\end{tabular}




\begin{tabular}{|l|l|l|l|l|l|}
\hline Industry total & 195 & & Industry total & 272 & \\
\hline \% in total relations (467) & 41.8 & & \% in total relations (467) & 58.2 & \\
\hline Average number of relations per firm & 24.4 & & Average number of relations per firm & 34.0 & \\
\hline Min/max o of relations & $10 / 44$ & & Min/max o of relations & $22 / 47$ & \\
\hline
\end{tabular}

Note: "Network size is measured by the number of the firm's direct dyadic ties" (Hite and Hesterly 2001: 278-

footnote 5), and network density of the firms is defined as total number of relationships of a firm divided by the total number of relationships in an industry.

Source: Own data

Table A.2. Distribution of face-to-face interviews by industry and types of interview

\begin{tabular}{|l|l|c|c|c|c|}
\hline & & \multicolumn{3}{|c|}{ Types of Interview } & \\
\hline & & One-to-one & Group & Spin-off & Total \\
\hline $\begin{array}{l}\text { Semi-structured } \\
\text { interviews }\end{array}$ & $\begin{array}{l}\text { Food- } \\
\text { processing firms }\end{array}$ & 12 & 4 & 0 & 16 \\
\cline { 2 - 6 } & Clothing firms & 9 & 4 & 2 & 15 \\
\hline $\begin{array}{l}\text { Open-ended } \\
\text { interviews }\end{array}$ & Organisations & 13 & 3 & 3 & 19 \\
\hline
\end{tabular}

Source: Own fieldwork

Table A.3. Operationalization of dependent variable (types of firm-level upgrading)

\begin{tabular}{|c|c|c|}
\hline $\begin{array}{l}\text { Dependent } \\
\text { variable }\end{array}$ & $\begin{array}{l}\text { Categories } \\
\text { of firm-level } \\
\text { upgrading }\end{array}$ & Operationalization \\
\hline \multirow{4}{*}{ 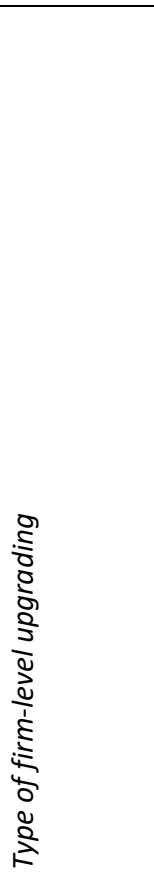 } & $\begin{array}{l}\text { Process } \\
\text { upgrading }\end{array}$ & $\begin{array}{l}\text { Investments in new machinery and equipment and new technology, introduction of advanced process } \\
\text { technologies (such as CAD, CAM, CIM, EDI, MRP/MRPII, automated storage and retrieval systems, } \\
\text { technical data network or factory network, resource planning in production department, etc.), } \\
\text { introduction of HACCP/ISO, introduction of new manufacturing processes, technical training of } \\
\text { workforce, changes in layout of the production processes and changes in production practices } \\
\text { Specifically in food-processing industry: Veterinary, microbiology, cooking/heating, freezing, } \\
\text { ingredients, process chemistry, mechanical engineering, automation, packaging / bottling. } \\
\text { Specifically in clothing industry: Garment dyeing/knitwear, design and engineering, CAD/prototyping, } \\
\text { pre-assembly (grading, marking, layering, plotting, cutting), materials handling/ conveyors/ new } \\
\text { systems, assembly (fusing, sewing, pressing/ironing, finishing), packaging and warehousing) }\end{array}$ \\
\hline & $\begin{array}{l}\text { Product } \\
\text { upgrading }\end{array}$ & $\begin{array}{l}\text { New brands, new models, new lines, new materials, new ingredients, new style; use of quality } \\
\text { supplies, change in technical characteristics. } \\
\text { Specifically In food-processing industry: New formulation, technology or packaging, or for a new } \\
\text { market, a new positioning. } \\
\text { Specifically in clothing industry: New material, new design, new style, new market, new positioning, } \\
\text { or new technology. }\end{array}$ \\
\hline & $\begin{array}{l}\text { Functional } \\
\text { upgrading }\end{array}$ & $\begin{array}{l}\text { Developing new functions that production units were not responsible for during communist regime, } \\
\text { such as purchasing, sales, marketing and distribution, design, quality. Includes developing capability to } \\
\text { purchase inputs from foreign markets, design own products, launch own products, coordinate own } \\
\text { supply chain, market and distribute own products, enter new markets, and so on. }\end{array}$ \\
\hline & $\begin{array}{l}\text { Managerial } \\
\text { upgrading }\end{array}$ & $\begin{array}{l}\text { New organisational and/ or management techniques, introduction or improvements of total quality } \\
\text { management, managers and workers training and attainment of qualifications, increased usage of } \\
\text { computing systems, internet/intranet for business purposes }\end{array}$ \\
\hline
\end{tabular}

Source: The fieldwork and the relevant literature (e.g. Navas-Aleman 2011) 
Table A.4 The variable external learning mechanisms and its categories with descriptions based on observations from this research

\begin{tabular}{|c|c|c|}
\hline $\begin{array}{l}\text { Categories of } \\
\text { EXTLEARN }\end{array}$ & $\begin{array}{c}\text { Associated type of } \\
\text { partner }\end{array}$ & Illustrative cases based on the observations from this research \\
\hline $\begin{array}{l}\text { Learning from } \\
\text { academic and } \\
\text { industrial } \\
\text { spillovers in a } \\
\text { relationship }\end{array}$ & $\begin{array}{l}\text { Competitors, firms } \\
\text { operating in similar } \\
\text { industrial specialisation } \\
\text { but not necessarily } \\
\text { competitors, (such as } \\
\text { global customers who are } \\
\text { brand manufacturers), } \\
\text { other horizontally-related } \\
\text { firms, universities, and } \\
\text { research institutes }\end{array}$ & $\begin{array}{l}\text { Strategic investor's supportive activities in managerial, technical, technological and/or scientific matters, } \\
\text { Cooperation with sister companies' research/product development units for product or process development, and among managers to keep track of } \\
\text { new developments in their market, } \\
\text { Managerial and technical harmonisation after merger with a horizontally-related firm, } \\
\text { Participation in conferences, seminars, scientific meetings that universities or industrial organisations such as Chambers of Commerce arrange, } \\
\text { Interactions at personal level in trade shows and fairs where competitors and horizontally-related firms participate, } \\
\text { Distribution licensing of a brand of a foreign horizontally related firm, } \\
\text { Visits to production plants of the partner or to machine supplier companies before technology acquisition, } \\
\text { Technical assistance by the representative of foreign partner located in the firm for a certain period of time to guide the production processes and } \\
\text { training provided by that person within the firm in order to improve the firm's production and technical capabilities to the desired advanced level of the } \\
\text { foreign partner, } \\
\text { Observing the products a foreign customer has requested or ordered and the associated production processes the customer taught or the machinery it } \\
\text { leased, } \\
\text { Personal informal contacts with academics at the universities, } \\
\text { Presence at the firm of post-graduate students and post-doctoral fellows as part of their degree work or joint projects (cf. Murray 2002). }\end{array}$ \\
\hline $\begin{array}{l}\text { Learning by } \\
\text { interacting in } \\
\text { a relationship }\end{array}$ & $\begin{array}{l}\text { Suppliers, customers, } \\
\text { users; complementary } \\
\text { firms and organisations in } \\
\text { and/or related to the } \\
\text { industry }\end{array}$ & $\begin{array}{l}\text { Subcontracting of a complementary firm for production purposes or of raw material suppliers (such as farmers in the food-processing industry) with } \\
\text { whom extensive scientific training is undertaken by the firm to introduce new advanced S\&T techniques, } \\
\text { Technical training by raw material supplier firm as to how to make use of its product in different ways, } \\
\text { Training by the global buyers and their technicians situated within the firm, } \\
\text { Projects with design firms, consulting firms for adapting and improving technical, organisational and managerial processes, for problem-solving, } \\
\text { Organisational and managerial training outside the company by consulting firms and universities } \\
\text { Marketing agencies before launching a new product on the market, } \\
\text { Market or product-related demands and feedbacks of wholesalers or hypermarkets, } \\
\text { Feedback loops between the firm and its supplier and customer. }\end{array}$ \\
\hline $\begin{array}{l}\text { Learning from } \\
\text { advances in } \\
\text { S\&T and } \\
\text { education in a } \\
\text { relationship }\end{array}$ & $\begin{array}{l}\text { Technology suppliers, } \\
\text { universities, research } \\
\text { institutes, laboratories, } \\
\text { specialised consulting or } \\
\text { intermediary firms for } \\
\text { international technology } \\
\text { transfer }\end{array}$ & $\begin{array}{l}\text { Technology acquisition and technical training during technology acquisition, } \\
\text { Licensing process technology, } \\
\text { Contracting research to the university, research institutes or labs for new ingredient, product, or process development, } \\
\text { Personal contacts with academics at the universities, generally for problem-solving in production processes, } \\
\text { Participation in advanced training and/or postgraduate programs of universities for technical, technological or scientific improvements, } \\
\text { Hiring skilled people, consultancy services for international technology transfer, } \\
\text { Accepting and paying PhD students or interns from the universities to study their topic in the firm, } \\
\text { Participation in research projects run by university as 'application' partner, } \\
\text { Joint projects with consulting firms for quality management (e.g. in food-processing industry) in order to get specific certifications and/or for IT-related } \\
\text { managerial training, } \\
\text { Participation in machinery exhibitions and interactions at personal level. }\end{array}$ \\
\hline
\end{tabular}

Source: Based on Malerba (1992) and von Tunzelmann and Wang (2007) with elaborations from own fieldwork. 
Table A.5 The variable internal learning mechanisms and its categories with descriptions based on observations from this research

\begin{tabular}{|c|c|}
\hline $\begin{array}{l}\text { Categories of } \\
\text { INTLEARN }\end{array}$ & Illustrative cases based on the observations from this research \\
\hline $\begin{array}{l}\text { Learning by doing } \\
+ \text { Learning by } \\
\text { imitating + } \\
\text { Learning failing }\end{array}$ & $\begin{array}{l}\text {-simply doing the manufacturing activity as it is shown to the employees to implement, } \\
\text {-replicating externally acquired knowledge for new product development, for entering into } \\
\text { new markets, for creating new niches in the domestic market and so on; } \\
\text {-replicating externally acquired knowledge for transfer of best practices, for on-the-job- } \\
\text { training; } \\
\text {-transforming externally acquired specific technological or scientific knowledge into a new } \\
\text { product or process development by people in research and product development unit, for } \\
\text { instance to develop a product or process new to the firm or to its market; } \\
\text {-applying externally acquired knowledge to the production process, so repetitively that it is } \\
\text { assimilated as if it has not come from outside the firm which over time leads to some minor } \\
\text { changes in production process or product development as a result of accumulated experience }\end{array}$ \\
\hline $\begin{array}{l}\text { Learning by using } \\
\text { + Learning by } \\
\text { monitoring }\end{array}$ & $\begin{array}{l}\text {-simply using externally acquired technology as it is shown to the employees; } \\
\text {-using externally acquired technology or knowledge for a specific purpose within the firm; } \\
\text {-transforming externally acquired data about the market into information which can actually } \\
\text { be used by the firm, for instance by the management to shape its strategy for responding to } \\
\text { changes in that market; } \\
\text {-using the feedback from the customers and users regarding the sale of their products in the } \\
\text { market for new product development, for market expansion and so on; } \\
\text {-transforming externally acquired specific technological or scientific knowledge, e.g. from } \\
\text { universities or research labs, into a new product or process; } \\
\text {-transforming externally acquired specialised knowledge, e.g. in IT use for managers, mostly } \\
\text { through outside training into organisational practice; } \\
\text {-systematically monitoring what other firms, competitors, suppliers are doing in their market } \\
\text { and what new products they are introducing, examining what the firm can do with its means } \\
\text { to keep up with them }\end{array}$ \\
\hline $\begin{array}{l}\text { Learning by } \\
\text { training and } \\
\text { research }\end{array}$ & $\begin{array}{l}\text {-sharing externally acquired knowledge for strategic planning or communities of practice } \\
\text { within the firm; } \\
\text {-sharing externally acquired knowledge between the researchers of the firm to use it for } \\
\text { adapting and improving existing technologies in use, for experimenting on specific tasks that } \\
\text { lead to trial and error experiences, and apply it in their research and product development; } \\
\text {-informal and formal training in specific areas for specific purposes within the group } \\
\text { companies, by sister companies, and within the firm, particularly following external } \\
\text { knowledge acquisition or training by global buyers, by technicians of global buyers situated } \\
\text { within the firm, by MNC subsidiaries as raw material suppliers to the firm, by technology } \\
\text { suppliers, by university departments (can be in management, in product development, in } \\
\text { production process improvements, in introducing new functions); } \\
\text {-informal and formal training undertaken by means of hiring a specialised organisation or } \\
\text { person within the firm, for example, in the reorganisation of production or introduction of } \\
\text { new marketing strategies by a consulting firm; } \\
\text {-informal and formal training practices within the firm with the aim of transferring the } \\
\text { knowledge acquired externally (e.g. as a result of technology acquisition) or by employee(s) } \\
\text { of the firm who were trained externally in specific subject area (including sales and } \\
\text { distribution people, franchisees); } \\
\text {-during a long-term relationship with suppliers (e.g. farmers), e.g., firm's agronomists work } \\
\text { with each farmer, teach and supervise them how to make most out of their harvest, } \\
\text { experiment on the land, simultaneously do laboratory research, and finally reflect on the } \\
\text { results of the yield each year to improve it next year; } \\
\text {-training suppliers by employees of a firm that is OBM in the domestic market (while } \\
\text { simultaneously being OEM in the export market), which requires the firm to set up a chain of } \\
\text { suppliers and then to train its suppliers in the same way the global buyer trained }\end{array}$ \\
\hline
\end{tabular}

Source: Based on Malerba (1992) and von Tunzelmann and Wang (2007) with elaborations from own fieldwork. 
Table A.6. Pearson Chi-Square test results for cross-tabulations between the dependent and each independent variable used in Upgrading Models

\begin{tabular}{lccc}
\hline & Test Statistics Pearson Chi-Square & \\
\hline $\begin{array}{l}\text { UPGTYPE vs } \\
\text { independent variables }\end{array}$ & Value & $\mathrm{df}$ & Two-sided Asymp. Sig. $(p)$ \\
\hline INDUSTRY & & & \\
PERIOD & 23.392 & 4 & 0.000 \\
EXTLEARN & 20.715 & 8 & 0.008 \\
INTLEARN & 138.618 & 12 & 0.000 \\
KNOWSHARE & 125.648 & 12 & 0.000 \\
\hline
\end{tabular}

Source: Own dataset, SPSS version 17.0

Table A.7 Cross-tabulation between external and internal learning mechanisms, and the Chi-Square Test results

\begin{tabular}{|c|c|c|c|c|c|c|c|c|c|c|}
\hline & & & \multicolumn{4}{|c|}{ INTLEARN } & \multicolumn{3}{|c|}{ SHARING } & \multirow[t]{2}{*}{ Total } \\
\hline & & & $\begin{array}{l}\text { doing+ } \\
\text { imitating } \\
\text { +failing }\end{array}$ & $\begin{array}{l}\text { using+ } \\
\text { monitori } \\
\text { ng }\end{array}$ & $\begin{array}{l}\text { interna } \\
\text { I } \\
\text { resourc } \\
\text { es }\end{array}$ & none & $\begin{array}{l}\text { withi } \\
n \text { unit }\end{array}$ & $\begin{array}{l}\text { inter- } \\
\text { unit/int } \\
\text { er- } \\
\text { persona } \\
\text { I }\end{array}$ & $\begin{array}{l}\text { Divisio } \\
\text { nal } \\
\text { /within } \\
\text { firm }\end{array}$ & \\
\hline \multirow{13}{*}{$\begin{array}{l}\text { EXTLEA } \\
\text { RN }\end{array}$} & \multirow{4}{*}{$\begin{array}{l}\text { know } \\
\text { spillover } \\
\text { s }\end{array}$} & Count & 20 & 34 & 52 & 19 & 40 & 49 & 36 & 125 \\
\hline & & $\begin{array}{l}\% \text { within } \\
\text { EXTLEAR } \\
\mathrm{N}\end{array}$ & $16.0 \%$ & $27.2 \%$ & $41.6 \%$ & $\begin{array}{l}15.2 \\
\%\end{array}$ & $\begin{array}{l}32.0 \\
\%\end{array}$ & $39.2 \%$ & $28.8 \%$ & $\begin{array}{l}100.0 \\
\%\end{array}$ \\
\hline & & $\begin{array}{l}\% \text { within } \\
\text { INTLEAR } \\
\mathrm{N}\end{array}$ & $17.2 \%$ & $26.6 \%$ & $39.7 \%$ & $\begin{array}{l}20.7 \\
\%\end{array}$ & $\begin{array}{l}22.3 \\
\%\end{array}$ & $23.7 \%$ & $44.4 \%$ & $\begin{array}{l}26.8 \\
\%\end{array}$ \\
\hline & & $\begin{array}{l}\% \text { of } \\
\text { Total }\end{array}$ & $4.3 \%$ & $7.3 \%$ & $11.1 \%$ & $4.1 \%$ & $8.6 \%$ & $10.5 \%$ & $7.7 \%$ & $\begin{array}{l}26.8 \\
\%\end{array}$ \\
\hline & \multirow{4}{*}{$\begin{array}{l}\text { S\&T } \\
\text { advance } \\
\text { s }\end{array}$} & Count & 2 & 59 & 29 & 19 & 63 & 28 & 18 & 109 \\
\hline & & $\begin{array}{l}\% \text { within } \\
\text { EXTLEAR } \\
\mathrm{N}\end{array}$ & $1.8 \%$ & $54.1 \%$ & $26.6 \%$ & $\begin{array}{l}17.4 \\
\%\end{array}$ & $\begin{array}{l}57.8 \\
\%\end{array}$ & $25.7 \%$ & $16.5 \%$ & $\begin{array}{l}100.0 \\
\%\end{array}$ \\
\hline & & $\begin{array}{l}\% \text { within } \\
\text { INTLEAR } \\
\mathrm{N}\end{array}$ & $1.7 \%$ & $46.1 \%$ & $22.1 \%$ & $\begin{array}{l}20.7 \\
\%\end{array}$ & $\begin{array}{l}35.2 \\
\%\end{array}$ & $13.5 \%$ & $22.2 \%$ & $\begin{array}{l}23.3 \\
\%\end{array}$ \\
\hline & & $\begin{array}{l}\% \text { of } \\
\text { Total }\end{array}$ & $.4 \%$ & $12.6 \%$ & $6.2 \%$ & $4.1 \%$ & $\begin{array}{l}13.5 \\
\%\end{array}$ & $6.0 \%$ & $3.9 \%$ & $\begin{array}{l}23.3 \\
\%\end{array}$ \\
\hline & \multirow{5}{*}{$\begin{array}{l}\text { by } \\
\text { interacti } \\
\text { ng }\end{array}$} & Count & 77 & 21 & 44 & 15 & 41 & 107 & 9 & 157 \\
\hline & & $\begin{array}{l}\% \text { within } \\
\text { EXTLEAR } \\
\mathrm{N}\end{array}$ & $49.0 \%$ & $13.4 \%$ & $28.0 \%$ & $9.6 \%$ & $\begin{array}{l}26.1 \\
\%\end{array}$ & $68.2 \%$ & $5.7 \%$ & $\begin{array}{l}100.0 \\
\%\end{array}$ \\
\hline & & $\begin{array}{l}\% \text { within } \\
\text { INTLEAR } \\
\mathrm{N}\end{array}$ & $66.4 \%$ & $16.4 \%$ & $33.6 \%$ & $\begin{array}{l}16.3 \\
\%\end{array}$ & $\begin{array}{l}22.9 \\
\%\end{array}$ & $51.7 \%$ & $11.1 \%$ & $\begin{array}{l}33.6 \\
\%\end{array}$ \\
\hline & & $\begin{array}{l}\% \text { of } \\
\text { Total }\end{array}$ & $16.5 \%$ & $4.5 \%$ & $9.4 \%$ & $3.2 \%$ & $8.8 \%$ & $22.9 \%$ & $1.9 \%$ & $\begin{array}{l}33.6 \\
\%\end{array}$ \\
\hline & & Count & 17 & 14 & 6 & 39 & 35 & 23 & 18 & 76 \\
\hline
\end{tabular}




\begin{tabular}{|c|c|c|c|c|c|c|c|c|c|c|}
\hline & \multirow[t]{3}{*}{$\begin{array}{l}\text { no } \\
\text { learning }\end{array}$} & $\begin{array}{l}\% \text { within } \\
\text { EXTLEAR } \\
N\end{array}$ & $22.4 \%$ & $18.4 \%$ & $7.9 \%$ & $\begin{array}{l}51.3 \\
\%\end{array}$ & $\begin{array}{l}46.1 \\
\%\end{array}$ & $30.3 \%$ & $23.7 \%$ & $\begin{array}{l}100.0 \\
\%\end{array}$ \\
\hline & & $\begin{array}{l}\% \text { within } \\
\text { INTLEAR }\end{array}$ & $14.7 \%$ & $10.9 \%$ & $4.6 \%$ & $\begin{array}{l}42.4 \\
\%\end{array}$ & $\begin{array}{l}19.6 \\
\%\end{array}$ & $11.1 \%$ & $22.2 \%$ & $\begin{array}{l}16.3 \\
\%\end{array}$ \\
\hline & & $\begin{array}{l}\% \text { of } \\
\text { Total }\end{array}$ & $3.6 \%$ & $3.0 \%$ & $1.3 \%$ & $8.4 \%$ & $7.5 \%$ & $4.9 \%$ & $3.9 \%$ & $\begin{array}{l}16.3 \\
\% \\
\end{array}$ \\
\hline \multirow[t]{9}{*}{ Total } & & Count & 116 & 128 & 131 & 92 & 179 & 207 & 81 & 467 \\
\hline & & $\begin{array}{l}\% \text { within } \\
\text { EXTLEAR } \\
N\end{array}$ & $24.8 \%$ & $27.4 \%$ & $28.1 \%$ & $\begin{array}{l}19.7 \\
\%\end{array}$ & $\begin{array}{l}38.3 \\
\%\end{array}$ & $44.3 \%$ & $17.3 \%$ & $\begin{array}{l}100.0 \\
\%\end{array}$ \\
\hline & & $\begin{array}{l}\% \text { within } \\
\text { INTLEAR } \\
N\end{array}$ & $100.0 \%$ & $100.0 \%$ & $100.0 \%$ & $\begin{array}{l}100.0 \\
\%\end{array}$ & $\begin{array}{l}100.0 \\
\%\end{array}$ & $100.0 \%$ & $100.0 \%$ & $\begin{array}{l}100.0 \\
\%\end{array}$ \\
\hline & & $\begin{array}{l}\% \text { of } \\
\text { Total }\end{array}$ & $24.8 \%$ & $27.4 \%$ & $28.1 \%$ & $\begin{array}{l}19.7 \\
\%\end{array}$ & $\begin{array}{l}38.3 \\
\% \\
\end{array}$ & $44.3 \%$ & $17.3 \%$ & $\begin{array}{l}100.0 \\
\%\end{array}$ \\
\hline & & Pearson C & hi-Square & & & & & & & \\
\hline & & Tests & & & & & & & & \\
\hline & & Value & $173.890^{\mathrm{a}}$ & & & & $\begin{array}{l}75.62 \\
9^{a}\end{array}$ & & & \\
\hline & & $\mathrm{df}$ & 9 & & & & 6 & & & \\
\hline & & $\begin{array}{l}\text { Asymp. } \\
\text { Sig. (2- } \\
\text { sided) }\end{array}$ & .000 & & & & .000 & & & \\
\hline
\end{tabular}

Table A.8 The first step of testing mediation between external learning mechanisms and knowledge internalisation variables (internal learning mechanisms)

\begin{tabular}{|c|c|c|c|c|c|c|c|c|}
\hline Mediation Test -S & $\begin{array}{l}\text { ep 1: Regressing learning } \\
\text { mechanisms }\end{array}$ & echat & sms in & rnal to th & m on exte & nal lea & & \\
\hline Logit functions & Variables & B & $\begin{array}{l}\text { Std. } \\
\text { Error }\end{array}$ & $\begin{array}{l}\text { Wald } \chi^{2} \\
\text { test }\end{array}$ & Sig. & $\begin{array}{l}\text { Odds } \\
\text { Ratio }\end{array}$ & $\begin{array}{l}95 \% \\
\text { Confid } \\
\text { Interv } \\
\text { Odds }\end{array}$ & \\
\hline & & & & & & & Lower & Upper \\
\hline learning by & Constant & -.57 & .43 & 1.72 & .190 & & & \\
\hline $\begin{array}{l}\text { doing + imitating } \\
\text { + failing vs no }\end{array}$ & $\begin{array}{l}\text { food-processing } \\
\text { vs clothing industry }\end{array}$ & -.80 & .33 & 5.82 & $0.016^{* *}$ & .45 & .23 & .86 \\
\hline & $\begin{array}{l}\text { late 1990s (1998-2001) } \\
\text { vs early 1990s (1989- } \\
\text { 1993) }\end{array}$ & .03 & .41 & .01 & .934 & 1.03 & .46 & 2.33 \\
\hline & $\begin{array}{l}\text { mid-1990s (1994-1997) } \\
\text { vs early 1990s (1989- } \\
\text { 1993) }\end{array}$ & -.15 & .47 & .10 & .752 & .86 & .34 & 2.18 \\
\hline & $\begin{array}{l}\text { learning from } \\
\text { knowledge spillovers } \\
\text { vs no learning }\end{array}$ & .95 & .44 & 4.70 & $0.030^{* *}$ & 2.59 & 1.10 & 6.11 \\
\hline & $\begin{array}{l}\text { learning from advances } \\
\text { in S\&T vs no learning }\end{array}$ & -1.24 & .81 & 2.39 & .122 & .29 & .06 & 1.40 \\
\hline & $\begin{array}{l}\text { learning by interacting } \\
\text { vs no learning }\end{array}$ & 2.45 & .41 & 36.05 & $0.000^{* * *}$ & 11.64 & 5.23 & 25.95 \\
\hline
\end{tabular}




\begin{tabular}{|c|c|c|c|c|c|c|c|c|}
\hline \multirow{9}{*}{$\begin{array}{l}\text { learning by using } \\
\text { + monitoring vs } \\
\text { no learning }\end{array}$} & Constant & -1.56 & .50 & 9.52 & \multicolumn{4}{|l|}{$0.002 * * *$} \\
\hline & \multicolumn{7}{|l|}{ vs clothing industry } & 1.57 \\
\hline & late 1990s (1998-2001) & .50 & .47 & 1.12 & .290 & 1.65 & .65 & 4.14 \\
\hline & \multicolumn{8}{|l|}{$\begin{array}{l}\text { vs early 1990s (1989- } \\
1993)\end{array}$} \\
\hline & mid-1990s (1994-1997) & 1.01 & .50 & 4.04 & $0.045^{* *}$ & 2.73 & 1.03 & 7.29 \\
\hline & \multicolumn{8}{|l|}{$\begin{array}{l}\text { vs early 1990s (1989- } \\
1993)\end{array}$} \\
\hline & $\begin{array}{l}\text { learning from } \\
\text { knowledge spillovers } \\
\text { vs no learning }\end{array}$ & 1.56 & .43 & 13.42 & $0.000 * * *$ & 4.78 & 2.07 & 11.03 \\
\hline & $\begin{array}{l}\text { learning from advances } \\
\text { in S\&T vs no learning }\end{array}$ & 2.16 & .42 & 26.50 & $0.000 * * *$ & 8.64 & 3.80 & 19.63 \\
\hline & $\begin{array}{l}\text { learning by interacting } \\
\text { vs no learning }\end{array}$ & 1.37 & .46 & 8.77 & $0.003 * * *$ & 3.94 & 1.59 & 9.78 \\
\hline \multirow{20}{*}{$\begin{array}{l}\text { learning by } \\
\text { training + } \\
\text { research vs no } \\
\text { learning }\end{array}$} & Constant & -1.78 & .54 & 10.85 & $0.001 * * *$ & & & \\
\hline & $\begin{array}{l}\text { food-processing } \\
\text { vs clothing industry }\end{array}$ & .01 & .30 & .00 & .976 & 1.01 & .56 & 1.82 \\
\hline & late 1990s (1998-2001) & -.03 & .41 & .01 & .942 & .97 & .43 & 2.18 \\
\hline & $\begin{array}{l}\text { vs early 1990s (1989- } \\
\text { 1993) }\end{array}$ & & & & & & & \\
\hline & mid-1990s (1994-1997) & -.31 & .47 & .46 & .500 & .73 & .29 & 1.82 \\
\hline & $\begin{array}{l}\text { vs early 1990s (1989- } \\
\text { 1993) }\end{array}$ & & & & & & & \\
\hline & $\begin{array}{l}\text { learning from } \\
\text { knowledge spillovers } \\
\text { vs no learning }\end{array}$ & 2.89 & .52 & 31.48 & $0.000 * * *$ & 18.06 & 6.57 & 49.63 \\
\hline & $\begin{array}{l}\text { learning from advances } \\
\text { in S\&T vs no learning }\end{array}$ & 2.29 & .54 & 18.30 & $0.000 * * *$ & 9.89 & 3.46 & 28.27 \\
\hline & $\begin{array}{l}\text { learning by interacting } \\
\text { vs no learning }\end{array}$ & 2.94 & .53 & 30.61 & $0.000 * * *$ & 18.89 & 6.67 & 53.50 \\
\hline & \multicolumn{4}{|l|}{ No of observations } & \multicolumn{4}{|l|}{467} \\
\hline & \multicolumn{4}{|l|}{ Log Likelihood } & \multicolumn{4}{|l|}{-121.407} \\
\hline & \multicolumn{4}{|l|}{ LR Chi-Square } & \multicolumn{4}{|l|}{194.551} \\
\hline & \multicolumn{4}{|l|}{ Degrees of freedom } & \multicolumn{4}{|l|}{18} \\
\hline & \multicolumn{4}{|l|}{ Prob $>$ Chi-Square } & \multicolumn{4}{|l|}{0.000} \\
\hline & \multicolumn{4}{|l|}{ Pseudo R2 (McFadden) } & \multicolumn{4}{|l|}{0.151} \\
\hline & \multicolumn{4}{|l|}{ Correct classification } & \multicolumn{4}{|l|}{$49.9 \%$} \\
\hline & \multicolumn{4}{|l|}{ Variable Selection } & \multicolumn{4}{|c|}{ Main effects } \\
\hline & \multicolumn{8}{|l|}{ Method used: } \\
\hline & \multicolumn{4}{|l|}{$\begin{array}{l}\text { Variable removed from } \\
\text { the MLR analysis: }\end{array}$} & \multicolumn{4}{|l|}{ NONE } \\
\hline & \multicolumn{4}{|l|}{ Reference outcome } & \multicolumn{4}{|c|}{ no learning during the relationship } \\
\hline
\end{tabular}


Table A.9 The first step of testing mediation between external learning mechanisms and knowledge internalisation variables (levels of knowledge sharing within the firm)

\begin{tabular}{|c|c|c|c|c|c|c|c|c|}
\hline \multicolumn{9}{|c|}{$\begin{array}{l}\text { Mediation Test -Step 1: Regressing levels of knowledge sharing within the firm on external learning } \\
\text { mechanisms }\end{array}$} \\
\hline \multirow[t]{2}{*}{ Logit functions } & \multirow[t]{2}{*}{ Variables } & \multirow[t]{2}{*}{ B } & \multirow[t]{2}{*}{$\begin{array}{l}\text { Std. } \\
\text { Error }\end{array}$} & \multirow[t]{2}{*}{$\begin{array}{l}\text { Wald } \chi^{2} \\
\text { test }\end{array}$} & \multirow[t]{2}{*}{ Sig. } & \multirow[t]{2}{*}{$\begin{array}{l}\text { Odds } \\
\text { Ratio }\end{array}$} & \multicolumn{2}{|c|}{$\begin{array}{l}\text { 95\% Confidence } \\
\text { Interval for } \\
\text { Odds Ratio }\end{array}$} \\
\hline & & & & & & & Lower & Upper \\
\hline \multirow[t]{9}{*}{ within unit } & Constant & .90 & .44 & 4.22 & .040 & & & \\
\hline & $\begin{array}{l}\text { food-processing } \\
\text { vs clothing industry }\end{array}$ & -.64 & .29 & 4.82 & .028 & .53 & .30 & .93 \\
\hline & late 1990s (1998- & .25 & .41 & .38 & .539 & 1.29 & .57 & 2.90 \\
\hline & $\begin{array}{l}\text { 2001) vs } \\
\text { early 1990s (1989- } \\
1993)\end{array}$ & & & & & & & \\
\hline & mid-1990s (1994- & -.18 & .44 & .16 & .687 & .84 & .35 & 1.98 \\
\hline & $\begin{array}{l}\text { 1997) vs } \\
\text { early 1990s (1989- } \\
1993)\end{array}$ & & & & & & & \\
\hline & $\begin{array}{l}\text { learning from } \\
\text { knowledge spillovers } \\
\text { vs no learning }\end{array}$ & -.49 & .38 & 1.72 & .190 & .61 & .29 & 1.28 \\
\hline & $\begin{array}{l}\text { learning from } \\
\text { advances in S\&T vS } \\
\text { no learning }\end{array}$ & .73 & .41 & 3.16 & .075 & 2.07 & .93 & 4.62 \\
\hline & $\begin{array}{l}\text { learning by } \\
\text { interacting } \\
\text { no learning }\end{array}$ & .86 & .47 & 3.26 & .071 & 2.35 & .93 & 5.96 \\
\hline \multirow{8}{*}{$\begin{array}{l}\text { inter-personal / } \\
\text { inter-unit }\end{array}$} & Constant & .57 & .47 & 1.47 & .225 & & & \\
\hline & $\begin{array}{l}\text { food-processing } \\
\text { vs clothing industry }\end{array}$ & -1.84 & .31 & 35.39 & .000 & .16 & .09 & .29 \\
\hline & late 1990s (1998- & .54 & .43 & 1.61 & .204 & 1.72 & .75 & 3.96 \\
\hline & $\begin{array}{l}\text { 2001) vs } \\
\text { early 1990s (1989- } \\
1993)\end{array}$ & & & & & & & \\
\hline & $\begin{array}{l}\text { mid-1990s (1994- } \\
\text { 1997) vs } \\
\text { early 1990s (1989- } \\
1993)\end{array}$ & .06 & .46 & .02 & .902 & 1.06 & .43 & 2.58 \\
\hline & $\begin{array}{l}\text { learning from } \\
\text { knowledge spillovers } \\
\text { vs no learning }\end{array}$ & .24 & .41 & .36 & .551 & 1.28 & .57 & 2.84 \\
\hline & $\begin{array}{l}\text { learning from } \\
\text { advances in S\&T vs } \\
\text { no learning }\end{array}$ & .63 & .47 & 1.81 & .178 & 1.88 & .75 & 4.69 \\
\hline & $\begin{array}{l}\text { learning by } \\
\text { interacting } \\
\text { no learning }\end{array}$ & 2.32 & .49 & 22.39 & .000 & 10.13 & 3.88 & 26.43 \\
\hline
\end{tabular}

No of observations

Log Likelihood

LR Chi-Square

Degrees of freedom 
Prob > Chi-Square

0.000

Pseudo R2

0.13

(McFadden)

Correct classification

$57.0 \%$

Variable Selection

Main effects

Method used:

Variable removed

NONE

from the MLR

analysis:

Reference outcome

no learning during the relationship

${ }^{* * *} p<0.01 ;{ }^{* *} p<0.05 ; * p<0.10 ;$ standard errors are in parenthesis. 
Table A.10 The third step of testing mediation between external learning mechanisms and knowledge internalisation variables

\begin{tabular}{|c|c|c|c|c|c|c|c|c|c|c|c|c|c|c|c|}
\hline \multirow{3}{*}{$\begin{array}{l}\text { Logit } \\
\text { functions }\end{array}$} & \multirow{3}{*}{ Variables } & \multicolumn{7}{|c|}{$\begin{array}{l}\text { Mediation Test -Step 3.1: Regressing levels of knowledge } \\
\text { sharing within the firm and external learning mechanisms on } \\
\text { types of firm-level upgrading }\end{array}$} & \multicolumn{7}{|c|}{$\begin{array}{l}\text { Mediation Test -Step 3.2: Regressing learning mechanisms } \\
\text { internal to the firm and external learning mechanisms on types } \\
\text { of firm-level upgrading }\end{array}$} \\
\hline & & \multirow[t]{2}{*}{ B } & \multirow[t]{2}{*}{$\begin{array}{l}\text { Std. } \\
\text { Error }\end{array}$} & \multirow[t]{2}{*}{$\begin{array}{l}\text { Wald } \\
\chi^{2} \\
\text { test }\end{array}$} & \multirow[t]{2}{*}{ Sig. } & \multirow[t]{2}{*}{$\begin{array}{l}\text { Odds } \\
\text { Ratio }\end{array}$} & \multicolumn{2}{|c|}{$\begin{array}{l}\text { 95\% Confidence } \\
\text { Interval for } \\
\text { Odds Ratio }\end{array}$} & \multirow[t]{2}{*}{$B$} & \multirow[t]{2}{*}{$\begin{array}{l}\text { Std. } \\
\text { Error }\end{array}$} & \multirow[t]{2}{*}{$\begin{array}{l}\text { Wald } \\
\chi^{2} \\
\text { test }\end{array}$} & \multirow[t]{2}{*}{ Sig. } & \multirow[t]{2}{*}{$\begin{array}{l}\text { Odds } \\
\text { Ratio }\end{array}$} & \multicolumn{2}{|c|}{$\begin{array}{l}95 \% \text { Confidence } \\
\text { Interval for Odds } \\
\text { Ratio }\end{array}$} \\
\hline & & & & & & & Lower & Upper & & & & & & Lower & Upper \\
\hline \multirow{13}{*}{$\begin{array}{l}\text { managerial } \\
\text { upgrading } \\
\text { vs no } \\
\text { upgrading }\end{array}$} & Constant & -1.14 & .88 & 1.67 & .196 & & & & -3.08 & .90 & 11.79 & $0.001 * * *$ & & & \\
\hline & $\begin{array}{l}\text { food-processing vs } \\
\text { clothing industry }\end{array}$ & .40 & .40 & .98 & .321 & 1.49 & .68 & 3.30 & .57 & .39 & 2.13 & .145 & 1.76 & .82 & 3.76 \\
\hline & $\begin{array}{l}\text { late 1990s (1998-2001) vs } \\
\text { early 1990s (1989-1993) }\end{array}$ & 3.00 & .86 & 12.19 & $0.000 * * *$ & 20.17 & 3.74 & 108.91 & 2.47 & .85 & 8.52 & $0.004^{* * *}$ & 11.83 & 2.25 & 62.12 \\
\hline & $\begin{array}{l}\text { mid-1990s (1994-1997) vs } \\
\text { early 1990s (1989-1993) }\end{array}$ & 1.99 & .87 & 5.25 & $0.022 * *$ & 7.30 & 1.33 & 40.06 & 1.87 & .88 & 4.50 & $0.034 * * *$ & 6.51 & 1.15 & 36.78 \\
\hline & $\begin{array}{l}\text { learning from knowledge } \\
\text { spillovers vs no learning }\end{array}$ & .06 & .50 & .02 & .897 & 1.07 & .40 & 2.83 & -.97 & .55 & 3.14 & $0.076 *$ & .38 & .13 & 1.11 \\
\hline & $\begin{array}{l}\text { learning from advances in } \\
\text { S\&T vs no learning }\end{array}$ & .94 & .59 & 2.57 & .109 & 2.55 & .81 & 8.04 & -.12 & .63 & .04 & .845 & .88 & .26 & 3.02 \\
\hline & $\begin{array}{l}\text { learning by interacting vs } \\
\text { no learning }\end{array}$ & -1.27 & .59 & 4.54 & $0.033 * *$ & .28 & .09 & .90 & -2.52 & .64 & 15.42 & $0.000 * * *$ & .08 & .02 & .28 \\
\hline & $\begin{array}{l}\text { learning by doing }+ \\
\text { imitating }+ \text { failing vs no } \\
\text { learning }\end{array}$ & & & & & & & & .51 & .64 & .64 & .424 & 1.67 & .48 & 5.84 \\
\hline & $\begin{array}{l}\text { learning by using + } \\
\text { monitoring vs no learning }\end{array}$ & & & & & & & & .68 & .57 & 1.42 & .234 & 1.97 & .65 & 5.99 \\
\hline & $\begin{array}{l}\text { learning by training + } \\
\text { research vs no learning }\end{array}$ & & & & & & & & 4.59 & .78 & 34.54 & $0.000 * * *$ & 98.84 & 21.36 & 457.29 \\
\hline & $\begin{array}{l}\text { within unit vs within firm / } \\
\text { divisional level }\end{array}$ & -2.82 & .53 & 28.34 & $0.000 * * *$ & .06 & .02 & .17 & & & & & & & \\
\hline & $\begin{array}{l}\text { inter-personal / inter-unit } \\
\text { vs within firm / divisional } \\
\text { level }\end{array}$ & -2.10 & .52 & 16.41 & $0.000 * * *$ & .12 & .04 & .34 & & & & & & & \\
\hline & Constant & -1.33 & .70 & 3.68 & $0.055^{* *}$ & & & & -.14 & .47 & .09 & .760 & & & \\
\hline
\end{tabular}




\begin{tabular}{|c|c|c|c|c|c|c|c|c|c|c|c|c|c|c|c|}
\hline \multirow{11}{*}{$\begin{array}{l}\text { process } \\
\text { upgrading } \\
\text { vs no } \\
\text { upgrading }\end{array}$} & $\begin{array}{l}\text { food-processing vs } \\
\text { clothing industry }\end{array}$ & -.16 & .34 & .22 & .640 & .85 & .43 & 1.67 & -.09 & .33 & .07 & .791 & .92 & .48 & 1.74 \\
\hline & $\begin{array}{l}\text { late 1990s (1998-2001) vs } \\
\text { early 1990s (1989-1993) }\end{array}$ & -.88 & .42 & 4.40 & $0.036 * *$ & .41 & .18 & .94 & -.61 & .42 & 2.12 & .146 & .54 & .24 & 1.24 \\
\hline & $\begin{array}{l}\text { mid-1990s (1994-1997) vs } \\
\text { early 1990s (1989-1993) }\end{array}$ & -1.21 & .46 & 6.95 & $0.008 * * *$ & .30 & .12 & .73 & -1.03 & .46 & 4.96 & $0.026 * *$ & .36 & .14 & .88 \\
\hline & $\begin{array}{l}\text { learning from knowledge } \\
\text { spillovers vs no learning }\end{array}$ & .95 & .48 & 3.84 & $0.050 * *$ & 2.58 & 1.00 & 6.68 & .41 & .49 & .70 & .404 & 1.51 & .58 & 3.94 \\
\hline & $\begin{array}{l}\text { learning from advances in } \\
\text { S\&T vs no learning }\end{array}$ & 2.93 & .54 & 29.51 & $0.000 * * *$ & 18.81 & 6.52 & 54.22 & 2.57 & .55 & 21.50 & $0.000 * * *$ & 13.08 & 4.41 & 38.79 \\
\hline & $\begin{array}{l}\text { learning by interacting vs } \\
\text { no learning }\end{array}$ & .59 & .46 & 1.63 & .202 & 1.81 & .73 & 4.47 & .19 & .48 & .16 & .689 & 1.21 & .47 & 3.10 \\
\hline & $\begin{array}{l}\text { learning by doing + } \\
\text { imitating + failing vs no } \\
\text { learning }\end{array}$ & & & & & & & & .14 & .47 & .09 & .758 & 1.16 & .46 & 2.89 \\
\hline & $\begin{array}{l}\text { learning by using + } \\
\text { monitoring vs no learning }\end{array}$ & & & & & & & & & .42 & 1.12 & .290 & 1.56 & .69 & 3.54 \\
\hline & $\begin{array}{l}\text { learning by training + } \\
\text { research vs no learning }\end{array}$ & & & & & & & & 1.91 & .71 & 7.32 & $0.007 * * *$ & 6.78 & 1.69 & 27.11 \\
\hline & $\begin{array}{l}\text { within unit vs within firm / } \\
\text { divisional level }\end{array}$ & 1.93 & .62 & 9.63 & $0.002 * * *$ & 6.91 & 2.04 & 23.44 & & & & & & & \\
\hline & $\begin{array}{l}\text { inter-personal / inter-unit } \\
\text { vs within firm / divisional } \\
\text { level }\end{array}$ & 1.01 & .65 & 2.41 & .120 & 2.75 & .77 & 9.83 & & & & & & & \\
\hline \multirow{7}{*}{$\begin{array}{l}\text { product } \\
\text { upgrading } \\
\text { vs no } \\
\text { upgrading }\end{array}$} & Constant & -2.24 & .87 & 6.63 & $0.010 * * *$ & & & & -2.81 & .83 & 11.54 & $0.001 * * *$ & & & \\
\hline & $\begin{array}{l}\text { food-processing vs } \\
\text { clothing industry }\end{array}$ & -.54 & .40 & 1.81 & .179 & .58 & .26 & 1.28 & -.57 & .40 & 2.08 & .149 & .56 & .26 & 1.23 \\
\hline & $\begin{array}{l}\text { late 1990s (1998-2001) vs } \\
\text { early 1990s (1989-1993) }\end{array}$ & -.10 & .48 & .05 & .830 & .90 & .35 & 2.31 & .03 & .49 & .00 & .954 & 1.03 & .39 & 2.71 \\
\hline & $\begin{array}{l}\text { mid-1990s (1994-1997) vs } \\
\text { early 1990s (1989-1993) }\end{array}$ & -.35 & .51 & .47 & .492 & .70 & .26 & 1.91 & -.14 & .54 & .07 & .789 & .87 & .30 & 2.49 \\
\hline & $\begin{array}{l}\text { learning from knowledge } \\
\text { spillovers vs no learning }\end{array}$ & 2.35 & .69 & 11.58 & $0.001 * * *$ & 10.50 & 2.71 & 40.67 & 2.06 & .72 & 8.27 & $0.004 * * *$ & 7.85 & 1.93 & 31.95 \\
\hline & $\begin{array}{l}\text { learning from advances in } \\
\text { S\&T vs no learning }\end{array}$ & 2.37 & .80 & 8.82 & $0.003 * * *$ & 10.67 & 2.24 & 50.84 & 2.44 & .84 & 8.44 & $0.004 * * *$ & 11.53 & 2.21 & 60.00 \\
\hline & $\begin{array}{l}\text { learning by interacting vs } \\
\text { no learning }\end{array}$ & 1.70 & .68 & 6.22 & $0.013^{* *}$ & 5.49 & 1.44 & 20.94 & 1.11 & .70 & 2.50 & .114 & 3.04 & .77 & 12.05 \\
\hline
\end{tabular}




\begin{tabular}{|c|c|c|c|c|c|c|c|c|c|c|c|c|c|c|c|}
\hline & $\begin{array}{l}\text { learning by doing + } \\
\text { imitating + failing vs no } \\
\text { learning } \\
\text { learning by using + } \\
\text { monitoring vs no learning } \\
\text { learning by training + } \\
\text { research vs no learning }\end{array}$ & & & & & & & & $\begin{array}{l}1.89 \\
.82 \\
2.60\end{array}$ & $\begin{array}{l}.61 \\
.62 \\
.84\end{array}$ & $\begin{array}{l}1.76 \\
9.65\end{array}$ & $\begin{array}{l}.184 \\
0.002 * * *\end{array}$ & $\begin{array}{l}2.27 \\
13.42\end{array}$ & $\begin{array}{l}.68 \\
2.61\end{array}$ & $\begin{array}{l}7.59 \\
69.06\end{array}$ \\
\hline & $\begin{array}{l}\text { within unit vs within firm / } \\
\text { divisional level } \\
\text { inter-personal / inter-unit } \\
\text { vs within firm / divisional } \\
\text { level }\end{array}$ & $\begin{array}{l}.38 \\
.73\end{array}$ & .63 & 1.38 & .240 & 2.08 & $\begin{array}{l}.43 \\
.61\end{array}$ & $\begin{array}{l}5.05 \\
7.09\end{array}$ & & & & & & & \\
\hline \multirow{11}{*}{$\begin{array}{l}\text { functional } \\
\text { upgrading } \\
\text { vs no } \\
\text { upgrading }\end{array}$} & Constant & -.69 & .59 & 1.35 & .246 & & & & -1.13 & .52 & 4.73 & $0.030 * *$ & & & \\
\hline & $\begin{array}{l}\text { food-processing vs } \\
\text { clothing industry }\end{array}$ & .16 & .33 & .24 & .625 & 1.17 & .62 & 2.23 & -.09 & .33 & .07 & .786 & .92 & .48 & 1.73 \\
\hline & $\begin{array}{l}\text { late 1990s (1998-2001) vs } \\
\text { early 1990s (1989-1993) }\end{array}$ & .70 & .43 & 2.67 & .103 & 2.02 & .87 & 4.71 & 1.00 & .46 & 4.78 & $0.029 * *$ & 2.72 & 1.11 & 6.66 \\
\hline & $\begin{array}{l}\text { mid-1990s (1994-1997) vs } \\
\text { early 1990s (1989-1993) }\end{array}$ & .07 & .46 & .02 & .880 & 1.07 & .43 & 2.65 & .50 & .50 & 1.00 & .317 & 1.65 & .62 & 4.40 \\
\hline & $\begin{array}{l}\text { learning from knowledge } \\
\text { spillovers vs no learning }\end{array}$ & .70 & .44 & 2.56 & .109 & 2.02 & .85 & 4.79 & .14 & .47 & .09 & .761 & 1.15 & .46 & 2.91 \\
\hline & $\begin{array}{l}\text { learning from advances in } \\
\text { S\&T vs no learning }\end{array}$ & -.02 & .64 & .00 & .974 & .98 & .28 & 3.45 & -.42 & .67 & .39 & .530 & .66 & .18 & 2.45 \\
\hline & $\begin{array}{l}\text { learning by interacting vs } \\
\text { no learning }\end{array}$ & .90 & .40 & 4.97 & $0.026 * *$ & 2.46 & 1.11 & 5.43 & .59 & .43 & 1.86 & .172 & 1.81 & .77 & 4.23 \\
\hline & $\begin{array}{l}\text { learning by doing }+ \\
\text { imitating }+ \text { failing vs no } \\
\text { learning }\end{array}$ & & & & & & & & .17 & .43 & .16 & .693 & 1.19 & .51 & 2.78 \\
\hline & $\begin{array}{l}\text { learning by using }+ \\
\text { monitoring vs no learning }\end{array}$ & & & & & & & & .10 & .45 & .05 & .832 & 1.10 & .46 & 2.65 \\
\hline & $\begin{array}{l}\text { learning by training + } \\
\text { research vs no learning }\end{array}$ & & & & & & & & 2.97 & .69 & 18.55 & $0.000 * * *$ & 19.54 & 5.05 & 75.57 \\
\hline & $\begin{array}{l}\text { within unit vs within firm / } \\
\text { divisional level }\end{array}$ & -.55 & .49 & 1.23 & .267 & .58 & .22 & 1.52 & & & & & & & \\
\hline
\end{tabular}


inter-personal / inter-unit

.32

.49

.44

.508

1.38

.53

3.57

level

No of observations

467

$-243.982$

467

Log Likelihood

310.660

LR Chi-Square

32

Prob > Chi-Square

.000

296.959

Pseudo R2 (McFadden)

.212

.000

Correct classification

$51.4 \%$

.203

Variable Selection Method

Main

$50.3 \%$

used:

effects

Main

Variable removed from the

NONE

effects

NONE

MLR analysis:

Reference outcome

no upgrading

${ }^{* * *} p<0.01 ;{ }^{* *} p<0.05 ; * p<0.10$; standard errors are in parenthesis. 